
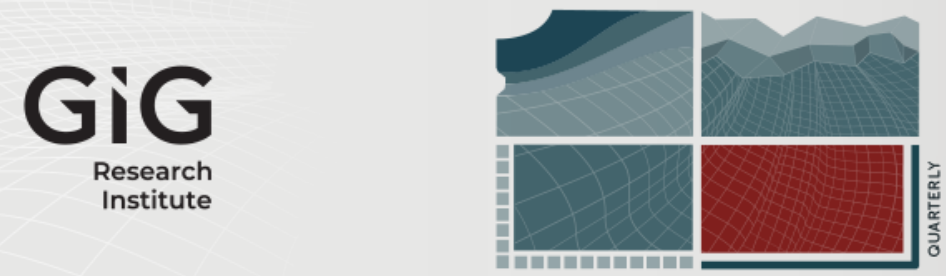

JOURNAL

OF

SUSTAINABLE

MINING

Volume 20 | Issue 2

Article 3

2021

\title{
Spatiotemporal Interactions between Surface Coal Mining and Land Cover and Use Changes
}

Author(s) ORCID Identifier:

Aikaterini Servou (iD 0000-0001-7814-706X

Christos Roumpos (iD) 0000-0001-9394-8041

Follow this and additional works at: https://jsm.gig.eu/journal-of-sustainable-mining

Part of the Applied Statistics Commons, Mining Engineering Commons, Other Environmental Sciences Commons, and the Sustainability Commons

\section{Recommended Citation}

Paraskevis, Nikolaos; Servou, Aikaterini; Roumpos, Christos; and Pavloudakis, Francis (2021)

"Spatiotemporal Interactions between Surface Coal Mining and Land Cover and Use Changes," Journal of Sustainable Mining: Vol. 20 : Iss. 2 , Article 3.

Available at: https://doi.org/10.46873/2300-3960.1053

This Research Article is brought to you for free and open access by Journal of Sustainable Mining. It has been accepted for inclusion in Journal of Sustainable Mining by an authorized editor of Journal of Sustainable Mining. 


\title{
Spatiotemporal Interactions between Surface Coal Mining and Land Cover and Use Changes
}

\author{
Abstract \\ Long-term surface mining and land cover and use changes have been evidenced to have a critical \\ relationship. This study conducts trend and correlation analysis by statistical tools to quantitatively \\ evaluate this relationship in the Ptolemais (Northern Greece) coal mining area for the period 1990-2018. \\ Firstly, based on Corine data and satellite images, a relative spatial indicator (RSI) was adopted to \\ describe the mineral land areas. Secondly, land cover and use changes were spatially defined using \\ Corine data and ArcGIS tools. The active mining area was then distinguished by dumping area, using \\ Landsat satellite imagery and mining maps, and finally, mine operation parameters were statistically \\ analyzed. The study revealed that "mineral extraction sites" present a strong correlation with "non \\ irrigated arable land" and "transitional woodland". The results have shown that between 1990 and 2018 \\ the total forest area was increased by three times, mainly as a result of the dumping sites geometry. \\ Additionally, the mine operation parameters are well correlated with the active mining area.

\section{Keywords} \\ Land Cover/Use Change, Surface Mining, Relative Spatial Indicator, Transitional Matrix, GIS, Active Mining \\ Area

\section{Creative Commons License} \\ (c) (1)
}

This work is licensed under a Creative Commons Attribution 4.0 License. 


\title{
Spatiotemporal interactions between surface coal mining and land cover and use changes
}

\author{
Nikolaos Paraskevis ${ }^{a}$, Aikaterini Servou ${ }^{a, b}$, Christos Roumpos ${ }^{a, *}$, Francis Pavloudakis ${ }^{a}$ \\ a Public Power Corporation of Greece, Department of Mining Engineering, 10432 Athens, Greece \\ ${ }^{\mathrm{b}}$ University of Patras, Department of Geology, 26504 Patras, Greece
}

\begin{abstract}
Long-term surface mining and land cover/use changes have been evidenced to have a critical relationship. This study investigates the evolution of this relationship for Ptolemais (Northern Greece) coal mining area during the period 1990-2018. In this context, satellite images, Corine data, and mining maps were used. A relative spatial indicator (RSI) was adopted to describe the mineral land areas and ArcGIS tools to define the land cover and use changes. Furthermore, mine operation parameters were statistically analyzed concerning land cover/use areas. The study revealed that areas described as "mineral extraction sites" present a strong correlation with "non-irrigated arable land" and "transitional woodland". From 1990 to 2018, the total forest area was increased by three times, mainly as a result of the dumping sites' geometry. Additionally, the mine operation parameters are well correlated with the active mining area, and more specifically, there is a linear relationship between the stripping ratio and the ratio of lignite production to active mining area. In the general case, the calculated annual changing rate of land use types may contribute to the prediction of future land reclamation uses and, consequently, to land reclamation planning in due time.
\end{abstract}

Keywords: land cover/use change, surface mining, relative spatial indicator, transitional matrix, GIS, active mining area

\section{Introduction}

$\mathrm{L}$ andscape changes are directly correlated with land use changes and the human factor to a certain extent [1,2]. In particular, the landscape changes occur due to anthropogenic activities, such as construction, mining, agriculture, and forest uses, representing $86 \%$ of changes to the landscapes [3]. In general terms, it is estimated that between $30 \%$ and $50 \%$ of the Earth's surface has been transformed or degraded by human activities [4].

Mining, especially continuous surface mining has a significant effect on the landscape, not only during the active mineral extraction period but also during post-mining operations. It causes irreversible changes in the environment and raises the most disputes than any other industry [5-7]. Mainly, modern surface mining techniques that include heavy equipment can produce dramatic alterations in land cover, both ecologically and hydrologically $[8,9]$. These alterations are a result of the land transformation induced by the mining excavations and dumps. Land cover and use changes should be reviewed, in order to investigate the relationship between landscape changes and mining, supporting land management and ecological reconstruction. The quantified spatial analysis and distribution of land changes are very important for pre-mining and post-mining planning, policy-making, and developmental planning [10]. Interactions and relationships between human activities and natural resources could be analyzed by studying landscape changes medium to long term [11]. Some main factors determine the impact of mining on the landscape and are distinguished into three categories. The first includes geological factors related to the deposit, such as the type of raw material, depth, resources, and availability. The second group includes factors associated with mining works, mainly the method of extraction, the size of mineral and waste rock extraction, the waste production, and the extraction period. The third group includes factors related to landscape features affected by mining,

Received 1 February 2021; revised 11 April 2021; accepted 18 April 2021.

Available online 25 May 2021.

* Corresponding author.

E-mail address: c.roumpos@dei.com.gr (C. Roumpos). 
such as the slope inclination, the intensity of relief, and the relative altitudes [12].

The selection of the appropriate method is of great importance, in order to identify the relationship between the mining activities and the changes in land cover/land use. The literature review shows several methods, some qualitative or expert-driven and some others quantitative or data-driven. The quantitative evaluation of landscape changes enables a better and more precise analysis of the change dynamics [13]. Additionally, there are four main categories of land use change models: Statistical and Econometric models, Spatial Interaction, Optimization, and Integrated models. Natural-sciences-oriented modeling, Markov modeling of land use change, and GIS-based modeling of land use change are some other modelling approaches [14]. Numerous studies have used the semi-quantitative method to detect and classify land cover and use changes through the visual interpretation of aerial photographs and satellite images based on the ArcGIS software applications [15-19]. In particular, the GIS database is updating by remote sensing images, and the remote sensing analysis is supported by GIS data [20-22].

In this context, the land cover and use changes between two different periods are depicted in the attribute table as the intersection's result of the two initial temporal layers [23]. Fragou et al. 2020 [24], proposed a synergistic use of Landsat EO imagery and Support Vector Machines (SVMs) for obtaining Land Use/Cover Mapping and quantifying its spatiotemporal changes. Also, the use of digital terrain models helps to explain the causes of the changes. One widespread technique for identifying the main land changes and trajectories is the intensity analysis and the classic transition matrix [25-28]. The Intensity analysis method is applied to analyze land changes at three levels: time interval, category, and transition [29]. Landscape transition matrices, land conversion maps, and landscape indices consist of techniques that identify the land change direction and quantify the change [30]. A quite reliable quantitative approach is that of $[2,31,32]$, which calculates some representative factors, namely landscape metrics, land use degree index, fractal dimension, land use stability index, etc. Landscape metrics are considered useful tools for quantifying landscapes' spatial patterns after the appropriate grain size or extent is determined [33].

The main research questions (RQ) are the following:

RQ 1: How do surface mining operations affect the land cover and use areas?
RQ 2: How are the land cover and use subcategories correlated?

RQ 3: How does the land cover and use changing rate operate as a critical tool for future land changes predictions?

RQ 4: How do mine operation parameters and land cover/use changes relate to each other over time?

The research questions have been addressed by investigating a) land cover and use changes in the Ptolemais lignite mining area and b) correlation between "mineral extraction sites", active mining area, and several lignite mine operation parameters.

The use of a Relative Spatial Indicator (RSI) is proposed, in combination with satellite imagery data and Corine dataset, in order to apply the spatial analysis of subcategory "mineral extraction sites". After the necessary adjustments, the land cover changes are investigated, focusing on the "mineral extraction sites" Corine subcategory. The main land cover subcategories (after appropriate merging) are statistically analyzed to investigate the intercorrelation. The final step is the relationship appraisal between the mineral land ("mineral extraction sites" and "active mining areas") and several mine operation parameters, like lignite production and stripping ratio.

This paper is divided into four sections. This section gives a brief overview of the land cover changes affected by surface mining; the second describes the study area, the data used in the frame of the study, and the applied methods. The third section presents the results and discussion while the conclusions are drawn in the final section.

\section{Materials and methods}

\subsection{Study area}

The exploitation of lignite mines by the Public Power Corporation (PPC) of Greece, in the Ptolemais mining area (Kozani Province of Western Macedonia Prefecture, northern Greece) started in 1957. A total of 1.5 billion tons of lignite had been mined in the Ptolemais area until the end of 2020, with total excavations of 6.8 billion $\mathrm{m}^{3}$ and an overall stripping ratio of $3.7 \mathrm{~m}^{3} / \mathrm{t}$. The corresponding total lignite production from all PPC mines in Greece was 2.2 billion tons and the total excavations 10 billion $\mathrm{m}^{3}$. The remaining lignite reserves in the area are estimated to about 600 million tons. At present, three mines (Mavropigi, Kardia, and South Field) are in operation, while the lignite production in 2020 was $8.25 \mathrm{Mt}$. According to the current planning, Kardia mine will stop operation in 2021, and the other two mines will operate till 2028. The 
higher annual lignite production rates were achieved during 2000-2012 (40-45 Mt annually).

The study area is defined within Approved Environmental Permitting Limits of Ptolemais mines $\left(147.91 \mathrm{~km}^{2}\right)$. It includes the excavation areas of surface mines in operation, the inside and outside dumping areas, former mining areas (exhausted mines and dumping areas) that have been reclaimed, as well as buildings and auxiliary facilities. The topography of the study area is generally sharp with elevations between 453 and $920 \mathrm{~m}$ a.s.l. Fig. 1 shows an overview of Ptolemais Mines within the Approved Environmental Permitting Limits.

\subsection{Study data}

The data that have been processed and analyzed was obtained from the CORINE dataset, Landsat images, and PPC data. CORINE (Coordination of information on the environment land cover) is a European project, which has been created for the recording of land cover/use of 27 member countries of the European Union [34]. It was initiated in 1985 (the reference year 1990). Updates have been produced in 2000, 2006, 2012, and 2018. The five years are the Corine landmark years of mapping the land cover and use changes. The changes regard some years before and after the landmark year [35]. It consists of an inventory of land cover in 44 classes. The depiction of European land cover is based on a combination of high-resolution satellite images and auxiliary elements $(1: 50,000$ and 1:100,000 scaled topographic maps, 1:30,000 scaled aerial photographs taken from 1986-1990 and 1:20,000 scaled orthophoto maps-the latest version of the Google Earth platform with very-high-resolution images was additionally utilized) [36].

The Landsat satellite data are available over some decades and free-of-charge through electronic access via the Web [37]. The spatial-resolution (30-meter) imagery of Landsat imagery enables users to see in detail processes such as urbanization, but not individual houses. The available information from Landsat imagery began in 1972 [38-42]. The satellite images covering the study area were

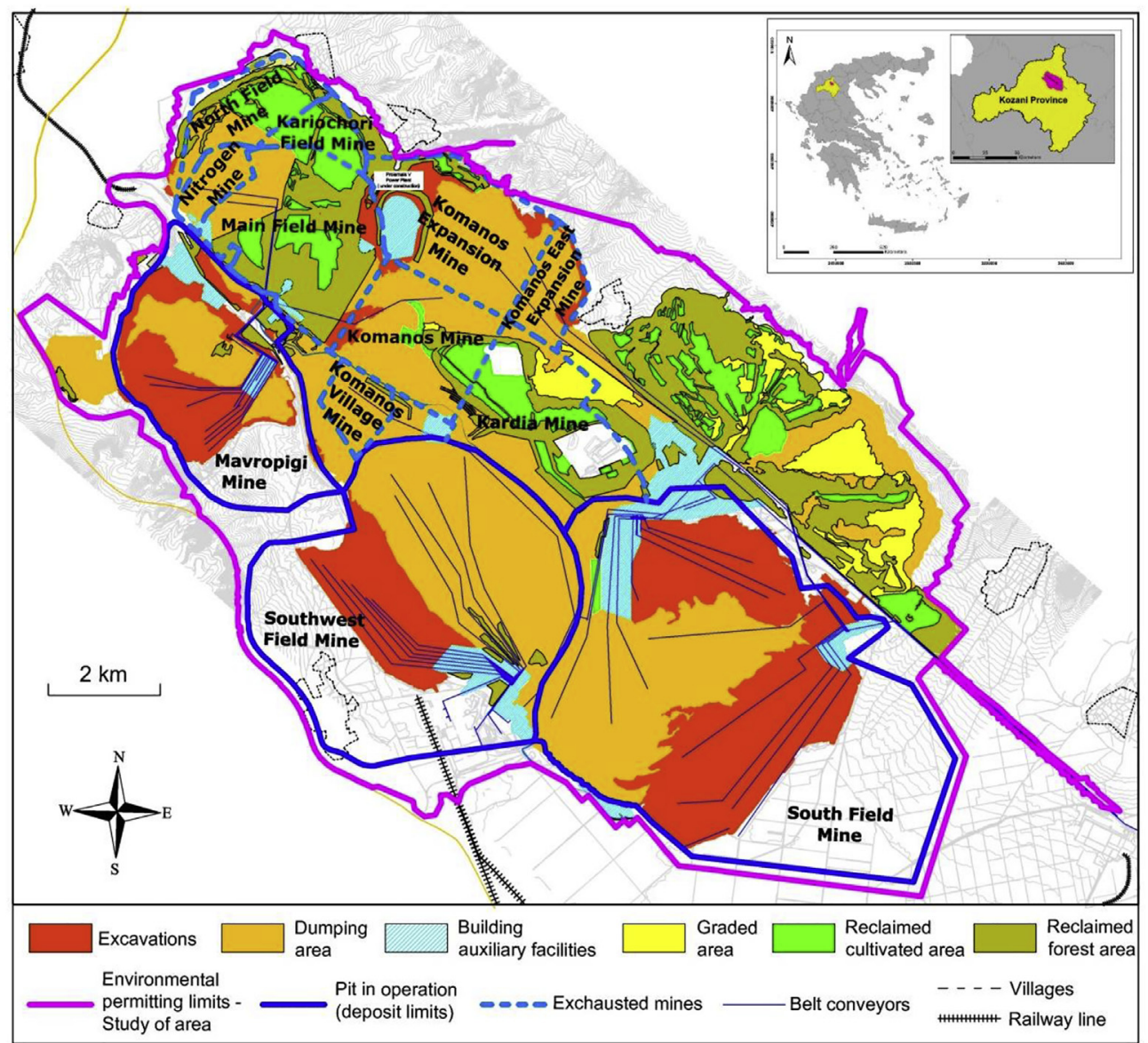

Fig. 1. Mines in operation and exhausted mines in Ptolemais area (June 2020) and reclaimed areas (December 2019). 
acquired for the period 1984-2018 and were obtained from the Earth Explorer (USGS).

Detailed annual topographical maps of the mining area, as well as technical, production, and spatial data of mining operation, were available by PPC. Furthermore, the study area scale is a crucial issue to consider, for mapping reasons, especially for the land cover mapping. In the study, all the data were projected to the same reference system and WGS 84 datum.

\subsection{Method}

The methodology followed three main processes: the first involves interpretation of Landsat satellite images of different years focusing on the mineral land, which is the area of interest in this study and overlaying with the Corine dataset. The second involves the surfaces' geometric intersection procedure in the ArcGIS environment. This procedure includes overlapping the features of two polygon shapefiles. Land cover and use area information is the containing data of the shapefiles for two different study years. In this way, detection, quantification, and spatially definition of land cover and use changes are achieved. Investigation of the relationship among several mine operation parameters with mineral land constitutes the third part of the study. The overall framework of the current analysis is summarized in Fig. 2.

\subsubsection{Mapping mineral land according to landsat} observations (Matching)

In some parts of the mining area, land cover changes have not been recorded in Corine dataset,

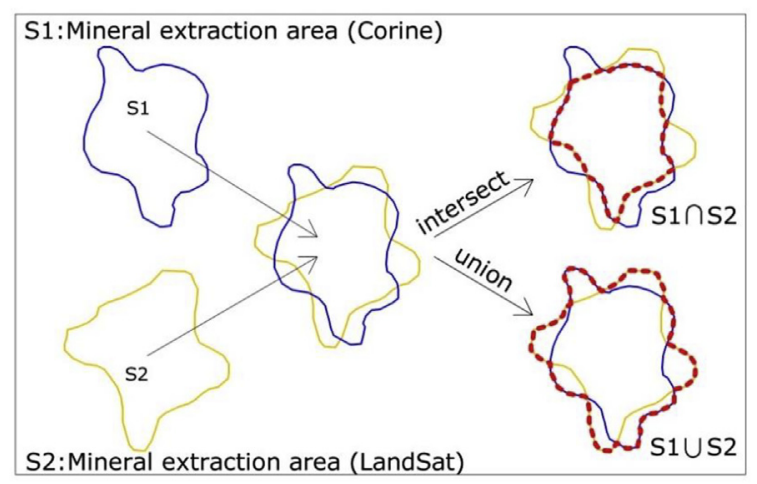

Fig. 3. Intersection and Union of two surfaces (Total theory).

although mining activities were developed between the years 2013-2018, and mines were expanded by excavating about $250 \mathrm{Mm}^{3}$. In this context, it was necessary to match and compare the Corine mineral land with Landsat mineral land to identify the similarities and differences. The process is based on the Set Theory (Fig. 3). It includes comparing two surfaces regarding relative location, shape, and area as polygon shapefiles in the ArcGIS software, using the Intersection and Union analysis tools.

The following proposed equation expresses the relationship between the two surfaces.

$R S I=\frac{\text { Intersection }}{\text { Union }}=\frac{S_{1} \cap S_{2}}{S_{1} \cup S_{2}}$

where

RSI is the Relative Spatial Indicator and applies $0 \leq R S I \leq 1$,

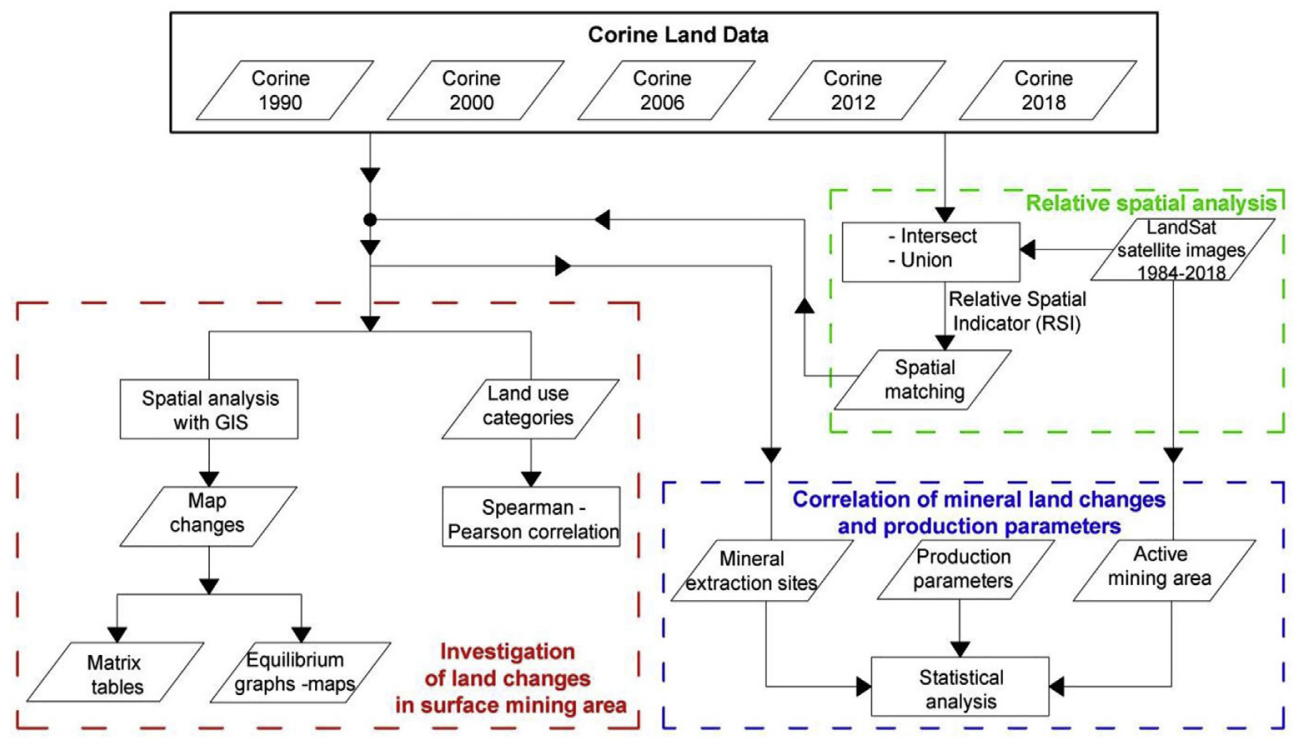

Fig. 2. Flow chart of the methodology. 
$\mathrm{S}_{1}$ is the mineral extraction area obtained by the Corine dataset and

$\mathrm{S}_{2}$ is the mineral extraction area based on Landsat satellite imagery

The visual interpretation was made in ArcGIS software 10.3.1, using the combination of the Landsat satellite images, the Land Corine dataset, and the data of different annual mine phases. After the georeferencing procedure in ArcGIS and the separation of the mining area from the dumps, the delineation of the polygons was employed. The Landsat satellite images' time range extends from 1984 until 2019, while the Land Corine's dataset reference years are: 1990, 2000, 2006, 2012, and 2018.

Predominately, the Land Corine dataset of the 1990 reference year was overlaid by Landsat images of 6 consecutive years $(1986,1987,1988,1989,1990$, and 1991), regarding only the "Mineral Extraction Sites" polygon (Fig. 4). More specifically, the "Mineral Extraction Sites" polygon was adjusted in the mineral land of satellite image for each year. The time consistency for Land Corine dataset 1990 regards the period 1986-1999. However, the matching procedure focused on 1986-1991, because the RSI reached the maximum value for the year 1988, and then began to decrease. The best combined Landsat image with the study polygon was finally selected for the change analysis. Determining the best combination, the RSI was calculated. In specific, the closer to 1 the RSI was, the better fitting appeared (Equation (1)). Regarding the difference observed during the period 2013-2018, the Corine Land Cover 2018 map's intervention has been

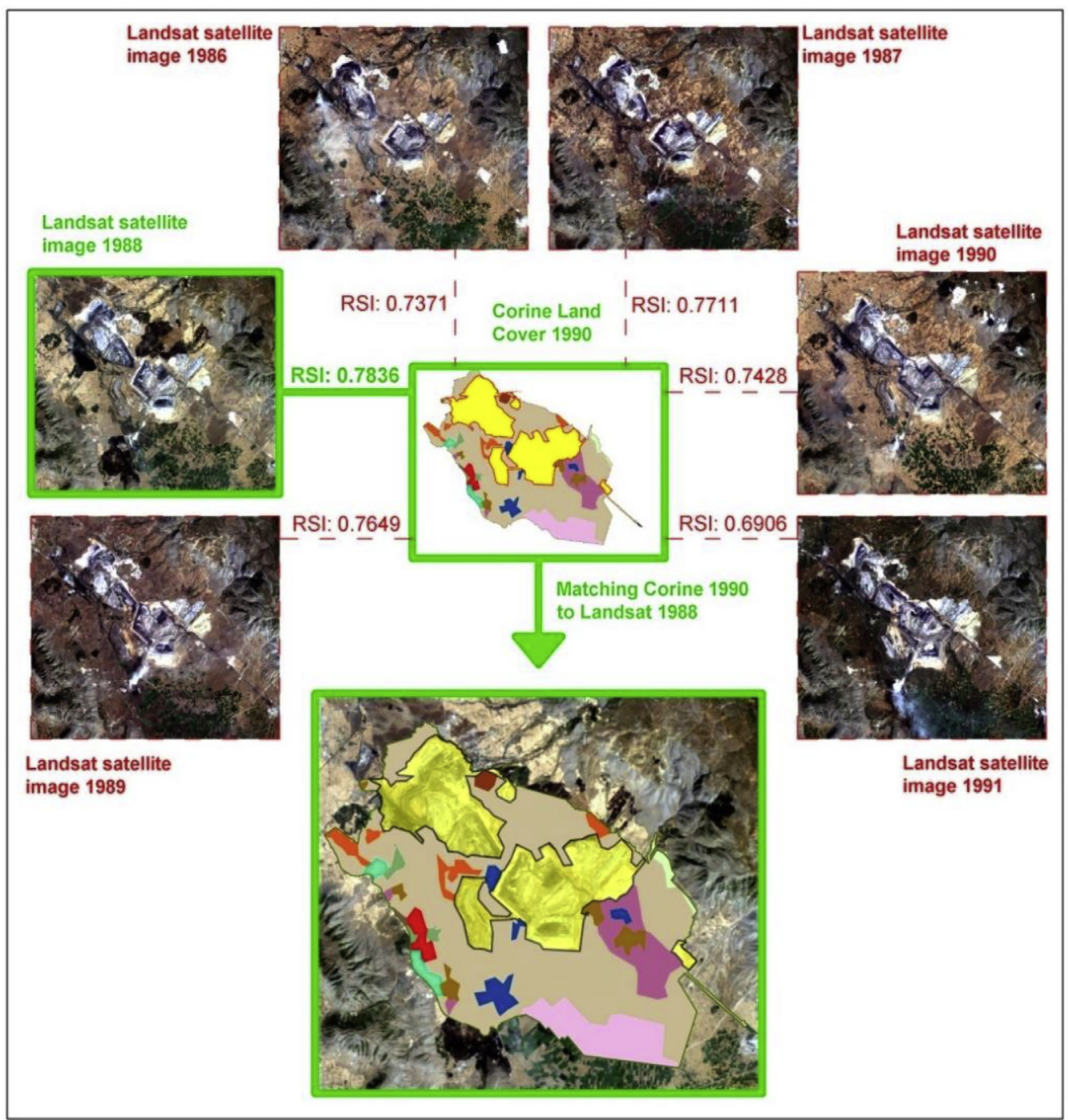

Fig. 4. Matching the "Mineral Extraction Sites" of Corine Data 1990 with the most suitable Landsat image according to RSI. 
accomplished according to the mining area interpretation of the 2017 Landsat satellite image. In the 2017 Landsat image, the highest value of RSI was observed compared with those of 2018 and 2019. This matching procedure aimed not to validate the Corine dataset, but to define as accurately as possible the "Mineral Extraction Sites", according to PPC experience.

Sixteen (16) different land cover and use subcategories were identified in the study area (Table 1). Their spatial distribution according to RSI is presented in Fig. 5. The Corine official nomenclature is presented, as well as the key code that has been adopted in this study for easiness. The "Mineral Extraction Sites" are described as follows: Category: Artificial surfaces- Subcategory: 1.3 Mine, dumps, and construction sites - 1.3.1 Mineral extraction sites [43]. In fact, "Mineral extraction sites" and "Dumps" are different Corine subcategories. However, in the Corine dataset, the "Mineral Extraction Sites" has not been distinguished from "Dumps". The active mining area (excavation area) was identified and separated from the dumping area in the third part of the paper, to be correlated with mine operation parameters.

\subsubsection{Calculation and mapping of land cover/use changes}

Land cover/use change detection is a significant task in digital image processing and is applied using two satellite images of different years [44]. The traditional detecting change methods using remote sensing data can be broadly divided into two main categories: pre-classification and post-classification image change detection. The pre-classification technique includes analysing transformed images from two different dates, whereas post-classification includes analysis of thematic classifications from two different date images [1,45-47]. The Post-Classification comparison (PCC) is the most commonly used method for quantitative analysis $[48,49]$. The post-classification change detection technique was chosen for use in this study. It permits analysing for a time series period, gives the size and distribution of changed areas (either negative or positive), as well as the percentages of other land cover classes that share in the change in each land cover class individually.

Transitional matrices were created to easily and in detail show the transition from one land cover/land use to another during time intervals [50]. The notation $P_{i j}$ is the land area that is transformed from subcategory $i$ to a different $j$. The overall sum of category $\mathrm{j}$, of the horizontal direction for the $\mathrm{P}_{\mathrm{i}, \mathrm{t} 1 \text {, }}$ indicates the land cover/use area in category $\mathrm{i}$ in time $t_{1}$ (Equation (2)). Similarly, the overall sum of category $i$, of the vertical direction for the $P_{j, t 2}$ indicates the landscape area in category $j$ in time $t_{2}$ (Equation (3)). In the diagonal direction, the area $P_{i i}$ refers to the unchanged part of the same category (Table 2).

$\sum_{j=1}^{n} P_{i j}=P_{i, t 1}$

$\sum_{i=1}^{n} P_{j i}=P_{i, t 2}$

The loss of terrain ( $\mathrm{Li}$ ) of category $\mathrm{P}_{\mathrm{ij}}$ from a former study year to a latter is calculated by the

Table 1. Land Cover/Land Use Corine subcategories that identified in the study area. The official nomenclature and the key code used in this study.

\begin{tabular}{llll}
\hline Corine official coding & Corine official Nomenclature & Key Code & Category \\
\hline 1.1 .2 & Discontinuous urban fabric & DUF & \\
1.2 .1 & Industrial or commercial units & ICU & \\
1.2 .2 & Road and rail networks and associated land & RN & ARTIFICIAL SURFACES \\
1.3 .1 & Mineral extraction sites & MES & \\
1.3 .3 & Construction sites & CS & NIAL \\
\hline 2.1 .1 & Non-irrigated arable land & PIL & \\
2.1 .2 & Permanently irrigated land & V & \\
2.2 .1 & Vineyards & P & AGRICULTURAL AREAS \\
2.3 .1 & Pastures & CCP & \\
2.4 .2 & Complex cultivation patterns & LAV & \\
2.4 .3 & Land principally & & \\
& occupied by agriculture, & & \\
& with significant areas of & & \\
\hline 3.1 .1 & natural vegetation & BLF & \\
3.2 .1 & Broad-leaved forest & NG & FOREST AND SEMI-NATURAL AREAS \\
3.2 .3 & Natural grasslands & SV & \\
3.2 .4 & Sclerophyllous vegetation & TW & \\
3.3 .3 & Transitional woodland-shrub & SVA & \\
\hline
\end{tabular}



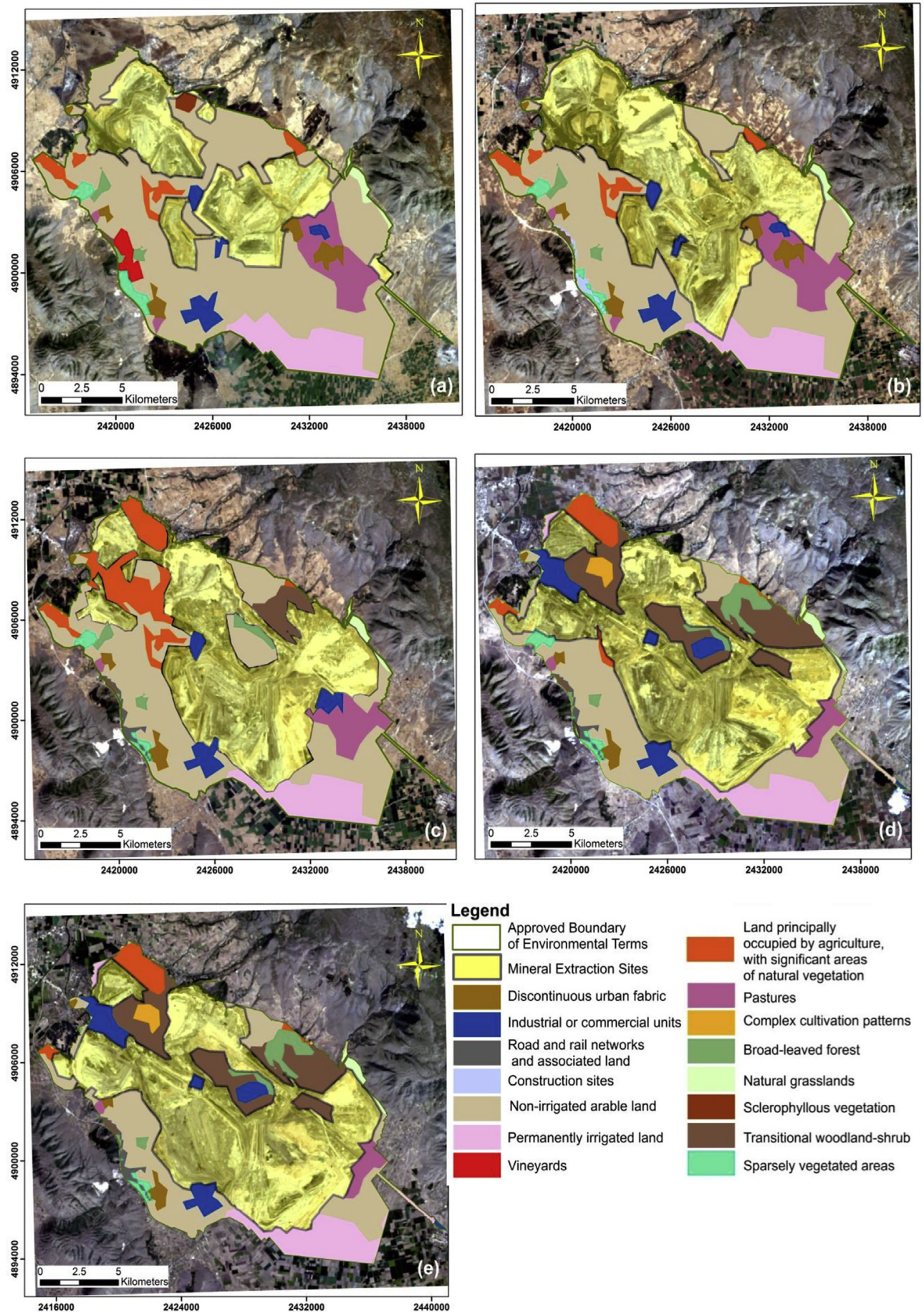

Fig. 5. The land cover/land use maps of the study area for five different years. Relative spatial matching of "Mineral Extraction Sites" polygon (Corine) and Landsat satellite image a) 1990, b) 2000 c) 2006, d) 2012, e) 2018.

difference between row totals and persistence (Equation (4)). The difference between column totals and persistence gives the gain of terrain (Gi) of category $\mathrm{P}_{\mathrm{ij}}$ in time $t_{2}$ by other categories from the year $t_{1}$ (initial time) to the year $t_{2}$ (next time) (Equation (5)).

$$
L i_{(t 1, t 2)}=P_{i(t 1)}-P_{i i}
$$

$$
G i_{(t 1, t 2)}=P_{i(t 2)}-P_{i i}
$$


Table 2. Theory of transitional matrix.

\begin{tabular}{lllllll}
\hline & \multicolumn{7}{c}{ Time $_{2}$} \\
\cline { 2 - 7 } & Category & 1 & 2 & $\ldots$ & $\mathrm{i}$ & $\mathrm{n}$ \\
\hline \multirow{3}{*}{ Time $\mathrm{t}_{1}$} & 1 & $\mathrm{P}_{11}$ & $\mathrm{P}_{12}$ & $\ldots$ & $\mathrm{P}_{1 \mathrm{i}}$ & $\mathrm{P}_{1 \mathrm{n}}$ \\
& 2 & $\mathrm{P}_{21}$ & $\mathrm{P}_{22}$ & $\ldots$ & $\mathrm{P}_{2 \mathrm{i}}$ & $\mathrm{P}_{2 \mathrm{n}}$ \\
& $\vdots$ & $\vdots$ & $\vdots$ & $\ddots$ & $\vdots$ & $\vdots$ \\
& $\mathrm{i}$ & $\mathrm{P}_{\mathrm{i} 1}$ & $\mathrm{P}_{\mathrm{i} 2}$ & $\ldots$ & $\mathrm{P}_{\mathrm{ii}}$ & $\mathrm{P}_{\mathrm{in}}$ \\
& $\mathrm{n}$ & $\mathrm{P}_{\mathrm{n} 1}$ & $\mathrm{P}_{\mathrm{n} 2}$ & $\ldots$ & $\mathrm{P}_{\mathrm{ni}}$ & $\mathrm{P}_{\mathrm{nn}}$ \\
\hline
\end{tabular}

$\operatorname{ARC}_{i}=\left(P_{i, t 2} / P_{i, t 1}\right)\left(\frac{1}{t_{2}-t_{1}}\right)-1$

where,

$P_{i, t 2}$ is the current value, $P_{i, t 1}$ the previous value $t_{1}$ the initial time, and $t_{2}$ the next time

The Annual Rate of change $\left(\mathrm{ARC}_{\mathrm{i}}\right)$ for each land covers subcategory i was calculated by Equation (6), which is based on the theory of Compound Interest.

\subsubsection{Spearman-Pearson correlation}

Spearman and Pearson correlation analyses were used between eight main land cover/use categories of Corine: "Mineral Extraction Sites (MES)", "Nonirrigated arable land (NIAL)", "Permanently irrigated land (PIL)", "Land principally occupied by agriculture, with significant areas of natural vegetation (LAV)", "Transitional woodland-shrub (TW)", "Other artificial surfaces (OAS)", "Other agricultural areas (OAA)" and "Other forest areas (OFA)". The (OAS) category consists of the following land cover subcategories: "Discontinuous urban fabric", "Industrial or commercial units", "Road and rail networks and associated land", and "Construction sites". The (OAA) category includes "Vineyards", and Complex cultivation patterns", whereas the (OFA) consists of "Broaded leaved forest", "Natural grasslands", "Schlerophyllous vegetation", and "Sparsely vegetated areas". The area for each land cover and use of the three categories is too small that the correlation is not possible. For this reason, the above grouping was chosen.

\subsubsection{Statistical analysis of mineral land and mine operation parameters}

Regression analysis was performed between mine operation parameters and mineral land, as well as among the mine operation parameters. Namely, mine operation parameters consist of stripping ratio and lignite production, while mineral land consists of "Mineral Extraction Sites" Corine subcategory and active mining area.

\section{Results and discussion}

\subsection{Mapping mineral land according to landsat observations (Matching)}

Fig. 5 presents the results of the matching procedure for each reference year based on the procedure described in the previous section and is schematically presented in Fig. 4. According to this, the RSI $_{1990}$ equals 0.7836 and the "Mineral Extraction Sites" matches well with the 1988 Landsat image (Fig. 5a). Following the same procedure for the other years, the $\mathrm{RSI}_{2000}=0.8935$ matches better with the 2000 Landsat image (Fig. 5b), the $\mathrm{RSI}_{2006}=0.8134$, matches with 2005 Landsat image (Fig. 5c), the $\mathrm{RSI}_{2012}=0.8380$ matches with 2011 Landsat image (Fig. 5d), and $\mathrm{RSI}_{2018}=0.8348$ matches with Landsat image of 2017 (Fig. 5e).

\subsection{Land cover and use changes over time}

The calculations of the various land cover and use acreages conducted in the ArcGIS software, for each one of the five study years within the period 1990-2018, and are presented in Fig. 6.

Moreover, a pairwise comparison of Corine reference years 1990-2000, 2000-2006, 2006-2012, 2012-2018, and 2000-2018 and a total of 1990-2018, were applied for land cover and use changes estimation. The "1 ${ }^{\text {st }}$ period" of $1990-2000$ is characterized by the rapid increase of rock excavation and lignite production rates and, as a consequence, the majority of the changes regard the transition from other uses to "Mineral Extraction Sites" (Fig. 7a). The " 2 nd period" of $2000-2018$, is characterized as the mature period (Fig. $7 \mathrm{~b}$ ) when mines' development and land reclamation works were carried out in parallel. Finally, in Fig. 7c the total transitional changes for the time interval 1990-2018 are mapped.

Fig. 8 shows the interaction between "Mineral Extraction Sites" and the other land cover/uses for each study year. The qualitative description of changes related to "mineral extraction sites" for the two general periods (1990-2000 and 2000-2018), as well as the change areas, are presented in the equilibrium charts of Fig. 9a and b.

The spatial distribution of land cover and use changes indicate that the reclamation works consist of a significant degree of forestation. Specifically, in 1990 the Corine category "Forests and semi-natural areas" occupied $4.5 \mathrm{~km}^{2}$, while in 2018 , the same category occupied an area of $19.5 \mathrm{~km}^{2}$, which means that there was an increase of approximately $330 \%$. $17.07 \mathrm{~km}^{2}$ out of $19.5 \mathrm{~km}^{2}$ of forest areas in 2018 are 


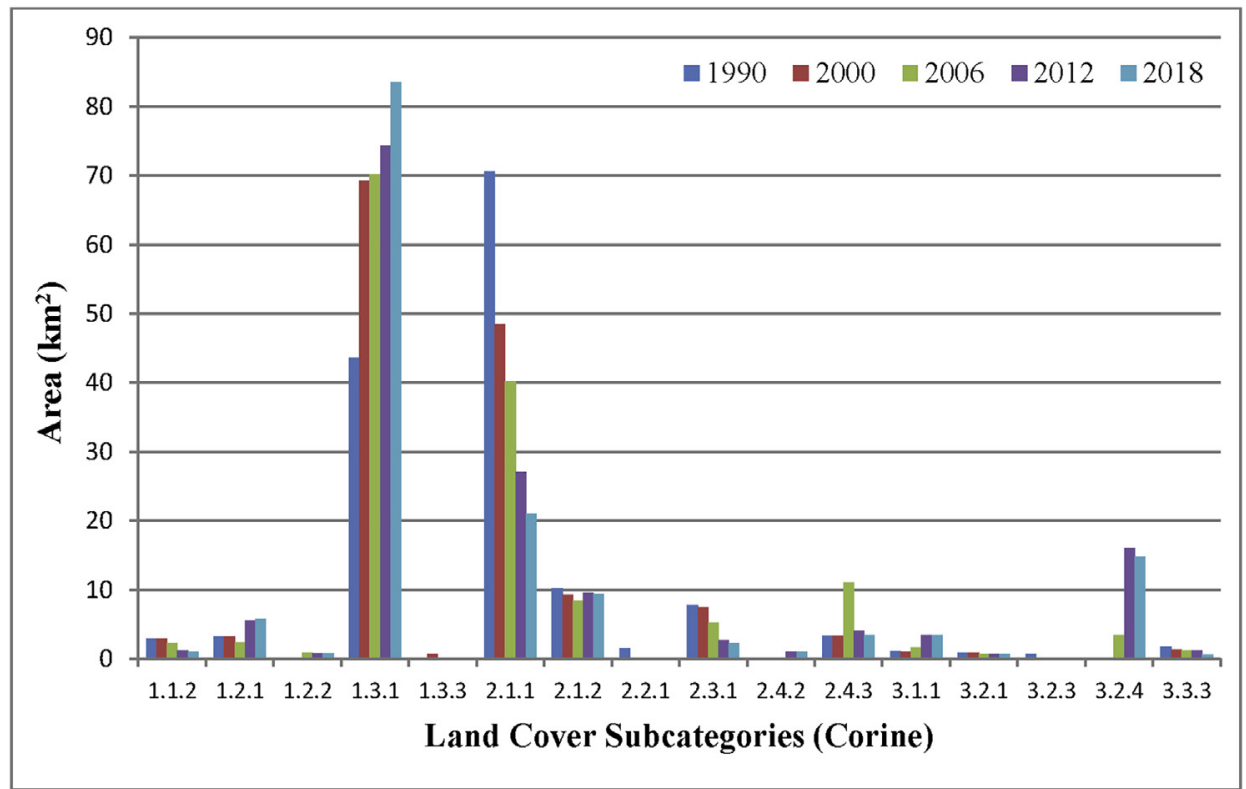

Fig. 6. Land cover and use areas per subcategory between the years 1990 and 2018; see Table 1 for the definition of the coding.

reclaimed land due to forestation works. The $1.82 \mathrm{~km}^{2}$ concerns the unchanged forest areas. It is worth noticing that "Transitional woodlands Shrubs" acreage exhibited a significant increase between 2006 and 2012. This is probably related to the extensive forestation programme carried out in the period 1995-2010. The relatively short time that has passed from the plantation of trees results in incomplete development of forests. Nevertheless, the achieved high-efficiency ratios of plantations promise that "Transitional Woodlands-Shrubs" will be transformed to "Broadleaved forests" after a few decades. As far as the "Agricultural areas" is of concern, its acreage has decreased by $60 \%$ for the same time interval. This development was expected since the predominant land use in the areas expropriated by the mine operator for mines development is "Non-irrigated arable land". Finally, the "Artificial surfaces" were increased by $80 \%$ due to the expansion of mining activity.

Furthermore, transitional matrices were created for the following study time intervals: 1990-2000, 2000-2006, 2006-2012, and 2012-2018. Tables 3 and 4 present the transitional matrices for the time intervals that have been defined as the two main mining periods (1990-2000 the development period of mines, and 2000-2018 the full operation and reclamation period). Also, a total transition matrix for the period 1990-2018 has been built (Table 5). Transitions from other uses to "Mineral Extraction Sites" appear with red colour, while green colour draws the transitions from "Mineral Extraction
Sites" to other uses. The unchanged areas are drawn with grey. The land cover and use areas are obtained from the Corine dataset. These transitions are spatially distributed in the maps of Fig. 10.

The most remarkable result to emerge from the data is the significant transformations that appeared among "Mineral Extraction Sites", "Non irrigated arable land", "Permanently irrigated land", and "Transitional woodland-shrub" (Tables 3-5). Summarizing the results, surface mining drastically changes landscape and land uses both during the development of mines and after the end of mining, through reclamation works (RQ1).

Fig. 11 shows the annual changing rate of main land use types during the period 1990-2018. It is worth referring that the higher value of annual rating change is observed during the period 2000-2006 in the forest land "Transitional Woodland". "Discontinuous Urban Fabric" was decreased during 2000-2018 due to the required expropriation of villages (Klitos, Haravgi, Mavropigi, Komanos) to develop mines. On the other hand, "Mineral Extraction Sites" remained unchanged during 2000-2006, even though lignite production and active mining area have been increased over the same period. The reasons are a) waste materials have been moved from outside to inside or other outside dumping areas for the further expansion of mines and b) extensive reclamation works have been carried out ("Land principally occupied by agriculture, with significant areas of natural vegetation", "Broad-Leaved Forest", and "Transitional Woodland") in areas where the 

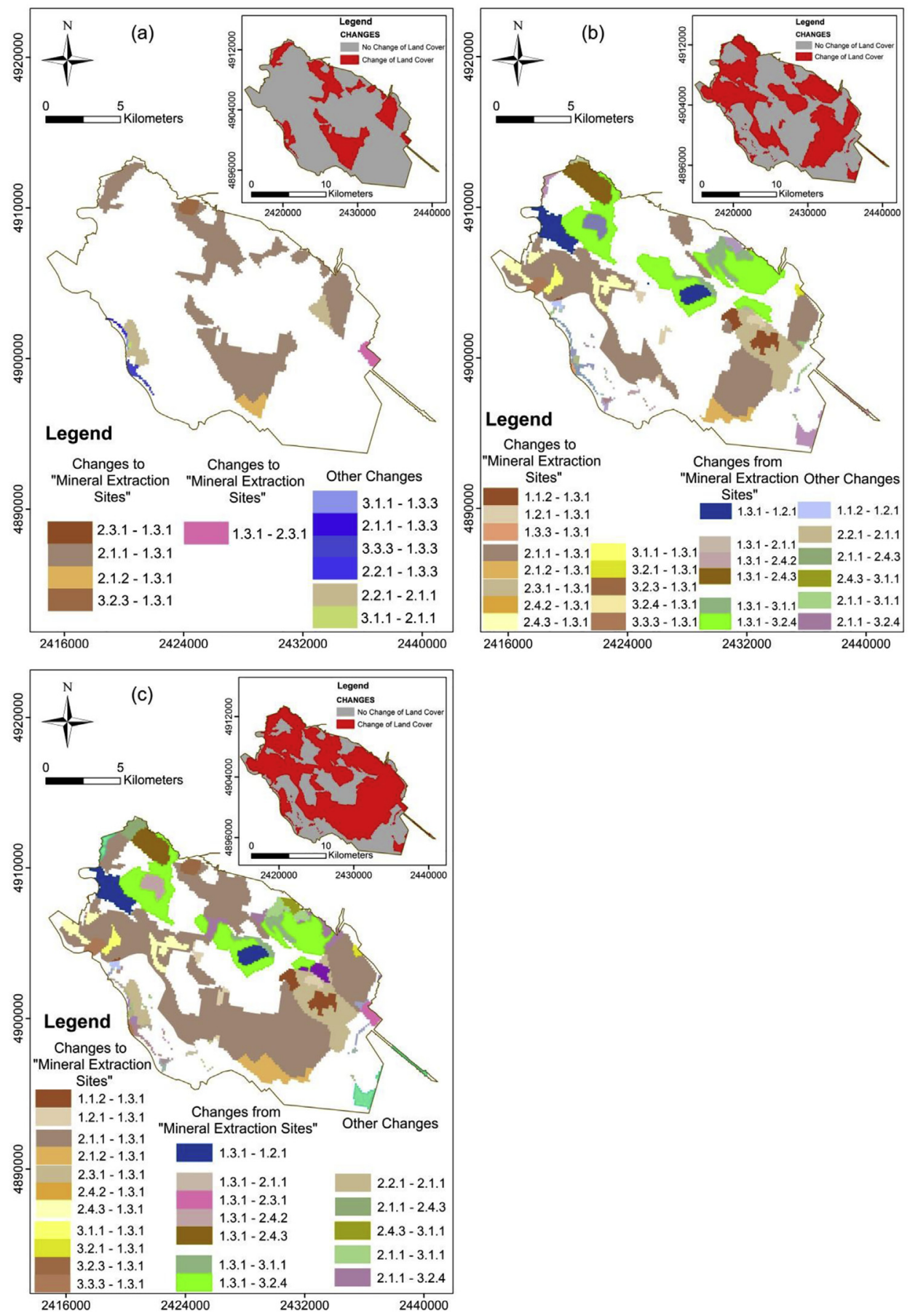

Fig. 7. Map of the most systematic land use and land cover transitions for the a) 1st period of mines development (1990-2000), b) 2nd period of mines development and reclamation (2000-2018), and c) the total transitions 1990-2018.

mining activity has been completed (exhausted mines and dumping areas).

The annual changing rate could be a useful tool for predicting land use changes in the future. However, considering additional factors, such as productivity, the type of land use, and the location of infrastructure (roads, railway lines, rivers, buildings), is necessary (RQ3).

\subsection{Land cover and use subcategories intercorrelation}

In the framework of this study, statistical correlations were employed using Spearman and Pearson techniques. The data used for the statistical analysis were areas data in $\mathrm{km}^{2}$. For the analysis scope, eight different land use types were selected, 


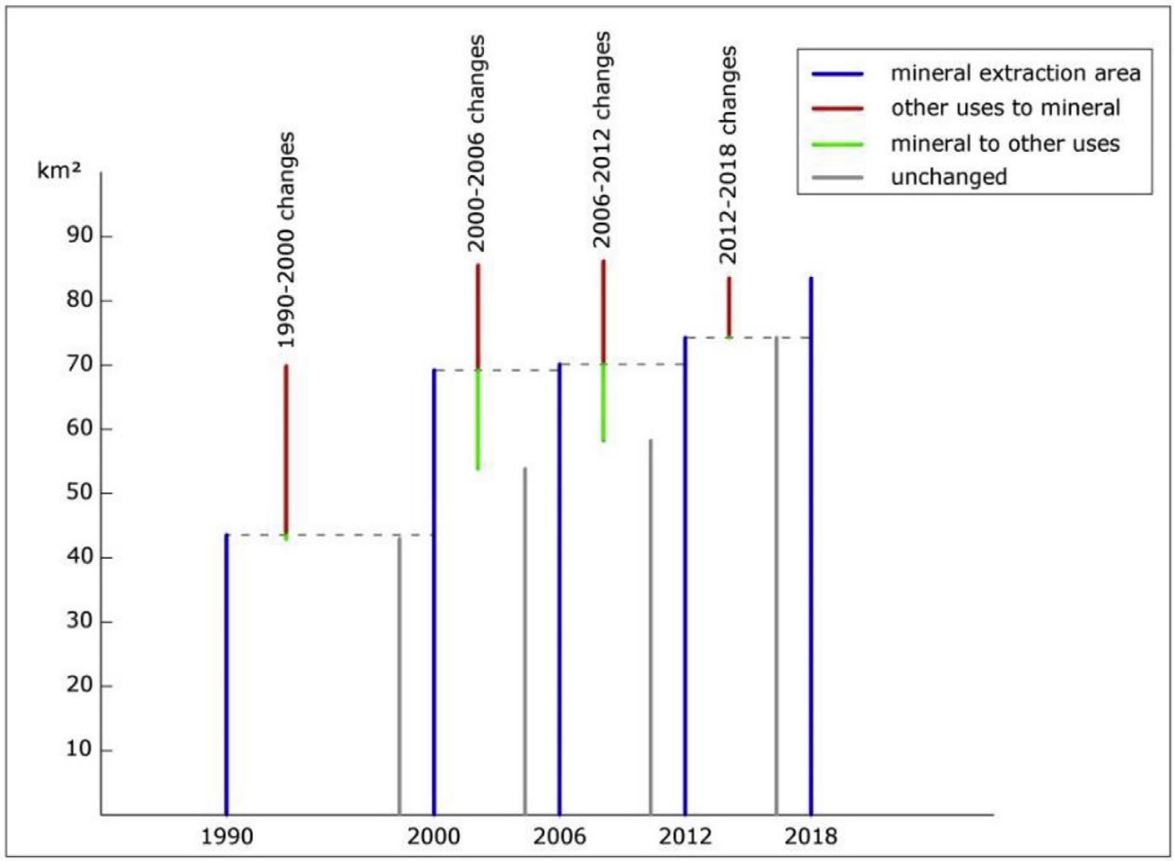

Fig. 8. Land cover changes regarding "Mineral Extraction Sites" during the study period.

of which the three are merged land use subcategories. The merging was conducted based on the common properties of the land use subcategories. Specifically, the smaller agricultural, artificial, and forest areas were merged. For each land use type, five values were used, which correspond to the five study years (Table 6). The closer to 1 the values are, the better correlation the two land

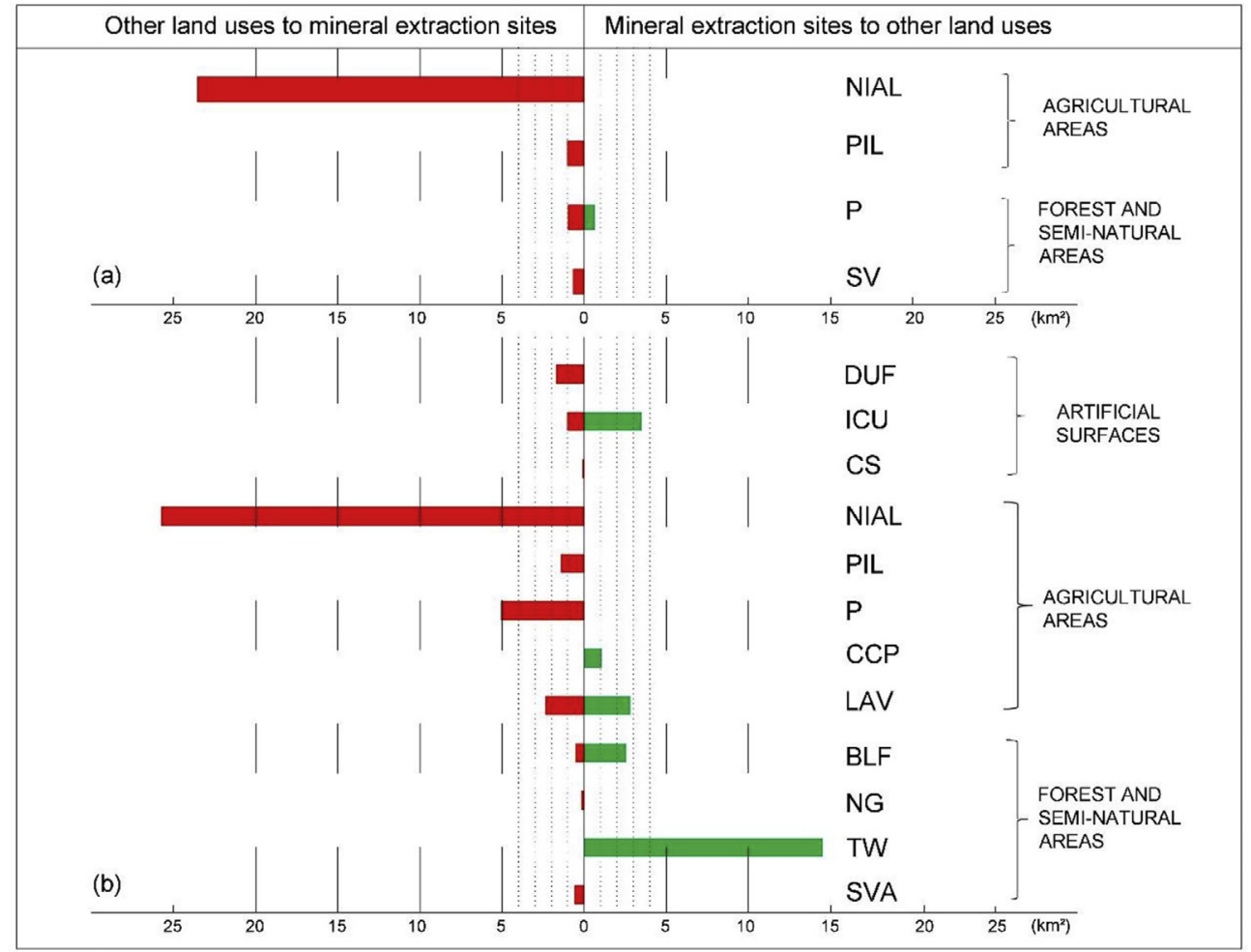

Fig. 9. Equilibrium Land Cover changes chart a) for the $1^{\text {st }}$ period 1990-2000 (mines development) and b) for the period 2000-2018 (mines in full operation and reclamation); (definition of the coding in Table 1). 
Table 3. Transitional matrices of land cover change for the period 1990-2000. Values are in square kilometers.

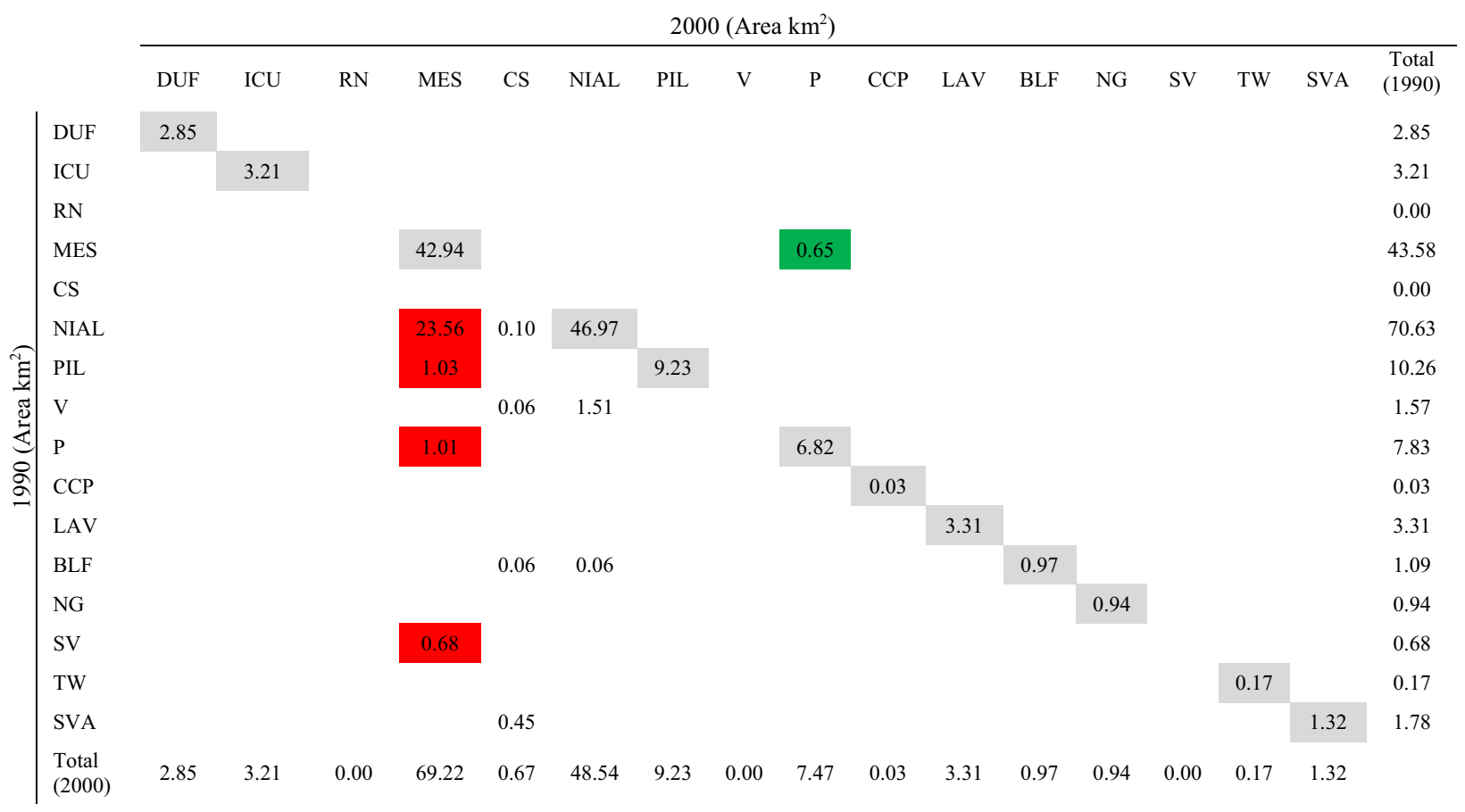

uses have. In Tables 7 and 8 , the correlations according to Pearson and Spearman are presented respectively, with a color scale. With red color, the lowest Pearson and Spearman absolute values are presented, with yellow the moderate, and with green the higher ones. The matrices were generated in statistical software SPSS, and the results included Pearson and Spearman correlation coefficient values with their significance.

In Tables 7 and 8 , it is observed that the majority of the correlation values belong to the moderate correlation (yellow color). The Spearman statistical

Table 4. Transitional matrices of land cover change for the period 2000-2018. Values are in square kilometers.

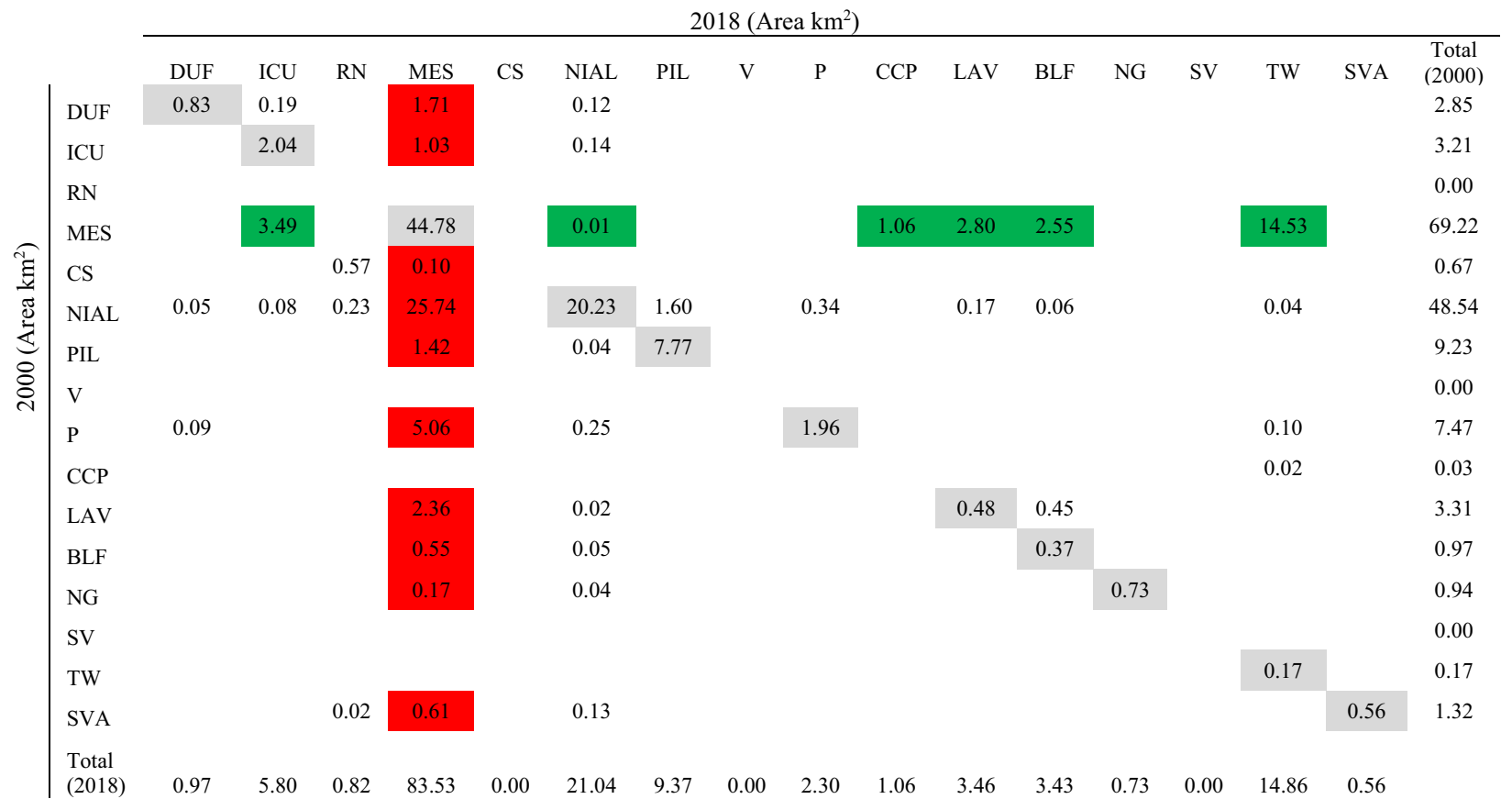


Table 5. Transitional matrices of land cover change for the period 1990-2018. Values are in square kilometers.

\begin{tabular}{|c|c|c|c|c|c|c|c|c|c|c|c|c|c|c|c|c|c|}
\hline & & & & & & & & $018(\mathrm{Ar}$ & $\mathrm{km}^{2}$ & & & & & & & & \\
\hline & DUF & $\mathrm{ICU}$ & $\mathrm{RN}$ & MES & $\mathrm{CS}$ & NIAL & PIL & $\mathrm{V}$ & $\mathrm{P}$ & CCP & LAV & BLF & NG & SV & $\mathrm{TW}$ & SVA & $\begin{array}{c}\text { Total } \\
\text { (1990) }\end{array}$ \\
\hline DUF & 0.83 & 0.19 & & 1.71 & & 0.12 & & & & & & & & & & & 2.85 \\
\hline ICU & & 2.04 & & 1.03 & & 0.14 & & & & & & & & & & & 3.21 \\
\hline $\mathrm{RN}$ & & & & & & & & & & & & & & & & & 0.00 \\
\hline MES & & 3.47 & & 22.59 & & 0.05 & & & 0.61 & 1.06 & 2.14 & 1.56 & & & 12.10 & & 43.58 \\
\hline $\mathrm{CS}$ & & & & & & & & & & & & & & & & & 0.00 \\
\hline NIAL & 0.05 & 0.10 & 0.18 & 45.81 & & 18.81 & 1.60 & & 0.34 & & 0.83 & 1.05 & & & 1.86 & & 70.63 \\
\hline PIL & & & & 2.45 & & 0.04 & 7.77 & & & & & & & & & & 10.26 \\
\hline V & & & 0.20 & & & 1.37 & & & & & & & & & & & 1.57 \\
\hline $\mathrm{P}$ & 0.09 & & & 5.47 & & 0.21 & & & 1.35 & & & & & & 0.70 & & 7.83 \\
\hline $\mathrm{CCP}$ & & & & & & & & & & & & & & & 0.03 & & 0.03 \\
\hline LAV & & & & 2.36 & & 0.02 & & & & & 0.48 & 0.45 & & & & & 3.31 \\
\hline BLF & & & 0.06 & 0.55 & & 0.11 & & & & & & 0.37 & & & & & 1.09 \\
\hline NG & & & & 0.17 & & 0.04 & & & & & & & 0.73 & & & & 0.94 \\
\hline SV & & & & 0.68 & & & & & & & & & & & & & 0.68 \\
\hline $\mathrm{TW}$ & & & & & & & & & & & & & & & 0.17 & & 0.17 \\
\hline SVA & & & 0.37 & 0.71 & & 0.13 & & & & & & & & & & 0.56 & 1.77 \\
\hline $\begin{array}{c}\text { Total } \\
\text { (2018) }\end{array}$ & 0.97 & 5.8 & 0.8 & 83.53 & & 21.04 & 9.37 & 0.00 & 2.30 & 1.06 & 3.46 & 3.43 & 0.73 & 0 & 14.86 & 0.56 & \\
\hline
\end{tabular}

analysis shows a perfect correlation regarding "Non-irrigated arable land", "Mineral Extraction Sites" and "Other Agricultural Areas". In particular, "Mineral Extraction Sites" seems to have a perfect negative correlation with the "Other Agricultural Areas" and the "Non-irrigated arable land". That happens due to the mining development operations and consequently the expansion of mining land onto the agricultural land, which, as already mentioned, was the main land use prior to the lignite mining era (Table 8). However, the "Mineral Extraction Sites" presents a good positive correlation with the "Transitional Woodland", which means that during the mining development, reclamation works were occurring simultaneously. The next most significant correlations occur among other subcategories, which are the "Other Agricultural Areas", the "Other Forest Areas", and the "Non-irrigated arable land" (RQ2).

The matrix plot of Fig. 12 displays the pairwise relationship of land cover/use subcategories. Critically, Spearman's statistical analysis proved to be more representative than the one of Pearson. There were observed higher values in Spearman
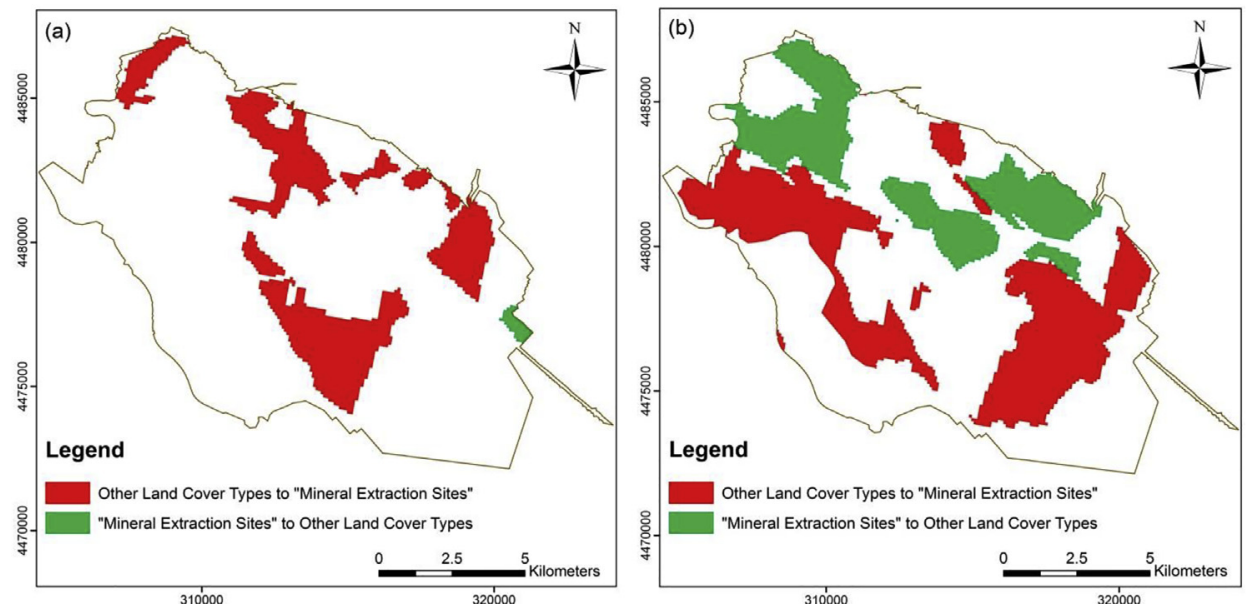

Fig. 10. Spatial changes distribution related with"Mineral Extraction Sites" for (a) 1990-2000, and (b) 2000-2018. 


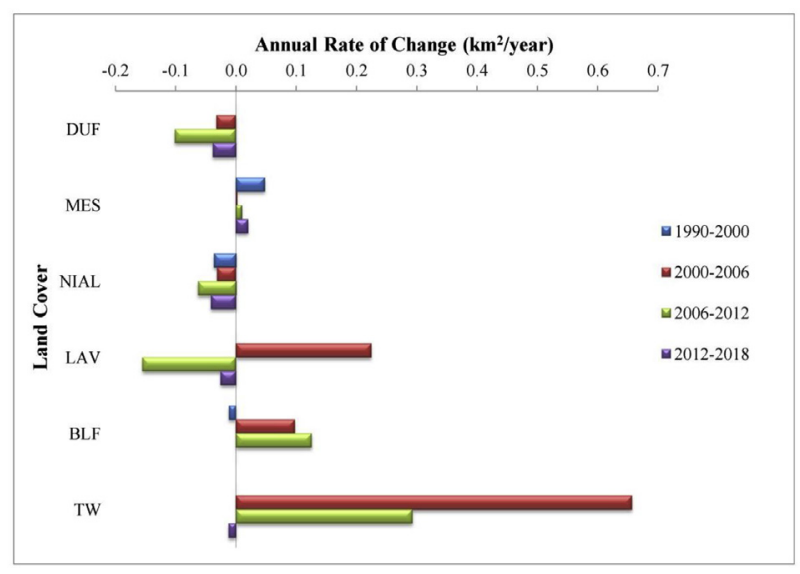

Fig. 11. Annual changing rate of each category (based on equation (6)); see Table 1 for the definition of the abbreviations.

Table 6. The initial cell values for the statistical analysis (Corine areas in $\mathrm{km}^{2}$ ).

\begin{tabular}{lllllllll}
\hline Year & \multicolumn{8}{l}{ Corine land cover and use areas } \\
\cline { 2 - 9 } & MES & NIAL & PIL & LAV & TW & OAS & OAA & OFA \\
\hline 1990 & 43.58 & 70.76 & 10.24 & 3.29 & 0.17 & 6.02 & 9.40 & 4.46 \\
2000 & 69.26 & 48.67 & 9.21 & 3.27 & 0.17 & 6.67 & 7.48 & 3.19 \\
2006 & 70.23 & 40.30 & 8.44 & 11.06 & 3.41 & 5.53 & 5.39 & 3.55 \\
2012 & 74.34 & 27.32 & 9.57 & 4.03 & 16.01 & 7.54 & 3.75 & 5.36 \\
2018 & 83.07 & 21.53 & 9.29 & 3.48 & 14.85 & 7.71 & 3.36 & 4.67 \\
\hline
\end{tabular}

correlation than in Pearson due to the monotonic and non-linear relationship that characterizes the parameters (Tables 7 and 8).

\subsection{Intercorrelation of mining parameters and correlation with the mineral land}

In the final part of the present work, the correlation between mine land changes and mine operation parameters has been investigated. For this purpose, the mine operation parameters that are considered for this correlation are lignite production and stripping ratio (ratio of waste rocks volume that must be excavated per ton of lignite produced). Lignite production during the period 1984-2019 is not related to changes in the acreage of "mineral extraction sites" Corine subcategory (Fig. 13). It must be noted that the latter includes both excavation and dumping areas and, in some cases, other areas, such as building infrastructures and auxiliary facilities. The excavation area (active mining area) should be identified and separated from dumping and infrastructure areas. In this frame, Landsat satellite images, and PPC data were used to determine the annual active mining area during the study period (1984-2019).

However, there has been a decrease in the active mining area in recent years, accompanied by a decrease in production. Fig. 13a shows the annual change of stripping ratio $\left(\mathrm{m}^{3} / \mathrm{t}\right)$ concerning lignite production per active mining area $\left(t / \mathrm{km}^{2}\right)$. As was expected, the stripping ratio is increased over time while lignite production per active mining area is decreased (Fig. 14). Moreover, in Figs. $13 \mathrm{~b}$ and c lignite production is related to the active mining area and the total mining area represented by the "mineral extraction sites". More specifically, lignite production increases as the active mining area increases. However, there is no correlation between the "mineral extraction sites" and lignite production because this subcategory includes both excavation and dumping areas. The decrease of lignite production after 2005 is amortized by the high stripping ratio, which increased the total volume of rocks wasted in dumping sites, which continue to expand up to now.

In general, the diachronically land cover and use changes occur due to the continuous surface mining

Table 7. Pearson correlation coefficients between the main land cover and use subcategories; see Table 1 for the definition of the abbreviations.

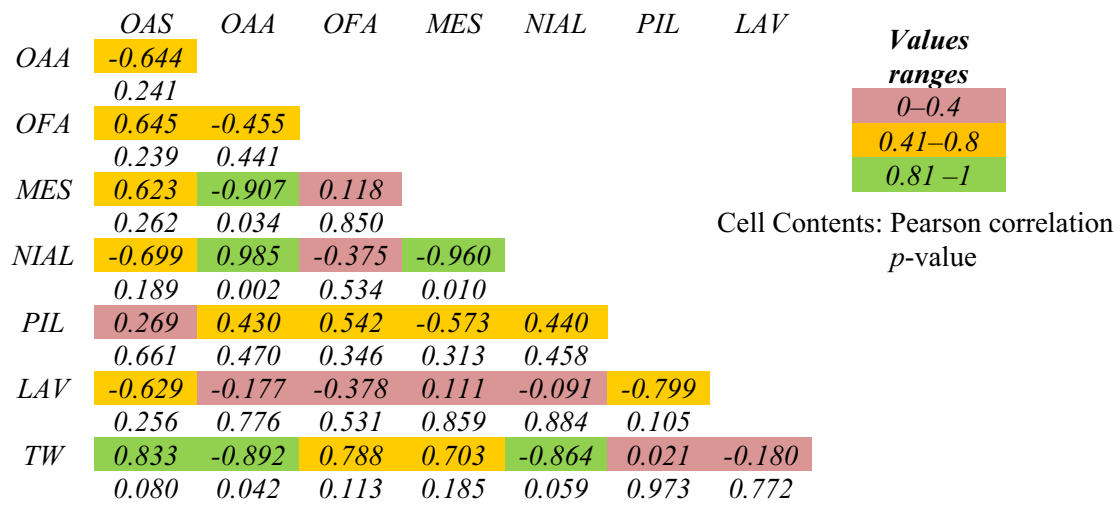


Table 8. Spearman Correlation coefficients between the main land cover and use subcategories; see Table 1 for the definition of the abbreviations.

\begin{tabular}{|c|c|c|c|c|c|c|c|c|}
\hline \multirow[b]{2}{*}{$O A A$} & $O A S$ & $O A A$ & $O F A$ & $M E S$ & $N I A L$ & $P I L$ & \multirow{3}{*}{\multicolumn{2}{|c|}{$\begin{array}{l}\text { Values } \\
\text { ranges }\end{array}$}} \\
\hline & $\begin{array}{r}-0.600 \\
0.285\end{array}$ & & & & & & & \\
\hline \multirow[t]{2}{*}{ OFA } & 0.700 & -0.600 & & & & & & \\
\hline & 0.188 & 0.285 & & & & & & $0-0.4$ \\
\hline \multirow[t]{2}{*}{ MES } & 0.600 & -1.000 & 0.600 & & & & & $0.41-0.8$ \\
\hline & 0.285 & * & 0.285 & & & & & $0.81-1$ \\
\hline \multirow[t]{2}{*}{ NIAL } & -0.600 & 1.000 & -0.600 & -1.000 & & & & $\begin{array}{l}\text { Correlation is } \\
\text { ignificant at the } 0.05\end{array}$ \\
\hline & 0.285 & * & 0.285 & * & & & & evel \\
\hline \multirow{2}{*}{$P I L$} & 0.400 & 0.200 & 0.600 & -0.200 & 0.200 & & \multirow{4}{*}{\multicolumn{2}{|c|}{$\begin{array}{c}\text { Cell Contents: Spearman rho } \\
\qquad p \text {-value }\end{array}$}} \\
\hline & 0.505 & 0.747 & 0.285 & 0.747 & 0.747 & & & \\
\hline \multirow[t]{2}{*}{$L A V$} & -0.051 & -0.564 & 0.308 & 0.564 & -0.564 & -0.462 & & \\
\hline & 0.935 & 0.322 & 0.614 & 0.322 & 0.322 & 0.434 & & \\
\hline \multirow[t]{2}{*}{$T W$} & 0.667 & -0.872 & 0.821 & 0.872 & -0.872 & 0.051 & 0.684 & \\
\hline & 0.219 & 0.054 & 0.089 & 0.054 & 0.054 & 0.935 & 0.203 & \\
\hline
\end{tabular}

and its long-term impacts, as well as the reclamation works that occur during the mine life cycle [51]. The mining activity in the study area proved to act as not only an effective procedure but also an environment up-gradation and seems to offer much more in the future, until the mine closure. The results of this study could be used as a guide for future land planning because they provide information regarding the annual changing rate of the land and the changes' quality. Furthermore, this study could be enriched and combined with a future one that will estimate the suitability for several land uses, for a completed post-mining land planning guide.

\section{Conclusion}

The mining operation in Ptolemais area began in 1957. Since then land cover and uses have undergone many changes. The active mining area was continuously increased, while reclamation works were carried out during the last 40 years to reduce landscape degradation and other environmental impacts. The present study investigates the evolution of land cover and uses in the period 1990-2018. For this period a dataset of Corine satellite images is available. The study found that the "Agricultural areas" category has directly or indirectly decreased by $60 \%$ due to the mining operations. However, at

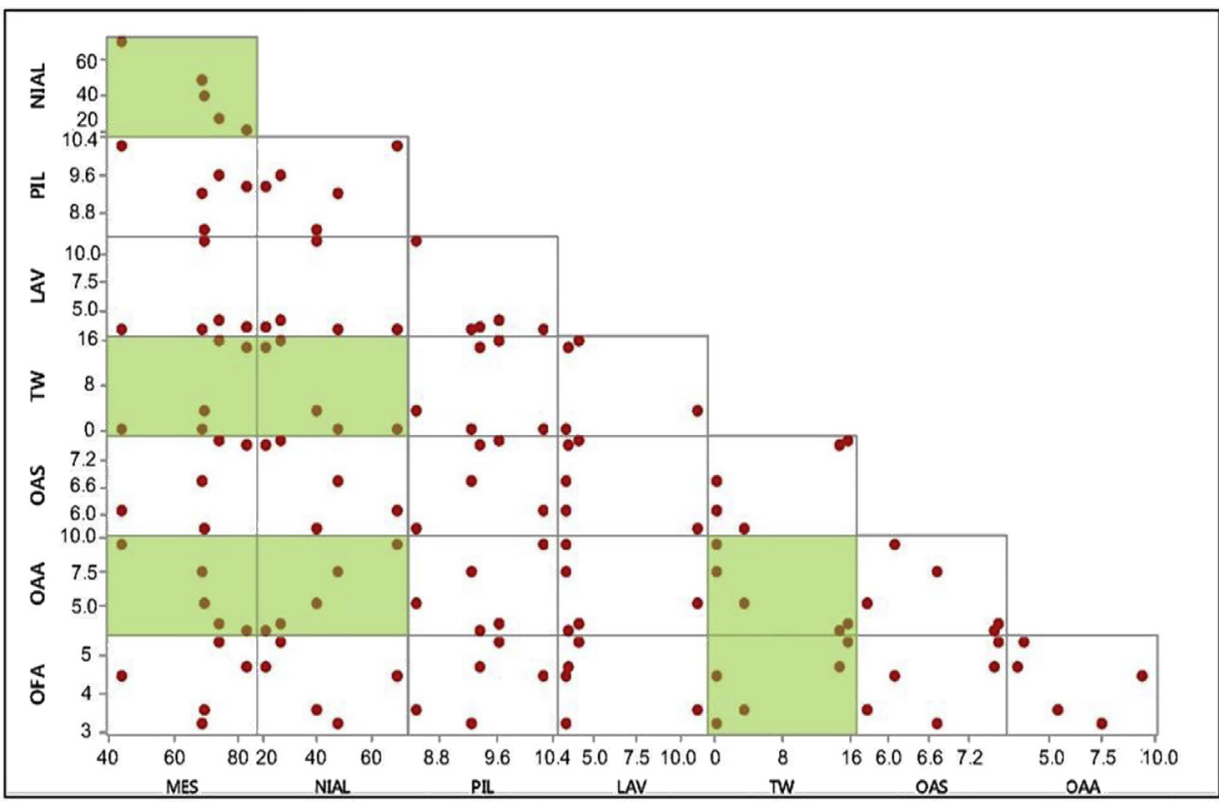

Fig. 12. Matrix Plot of eight land cover Corine subcategories (coloured areas according to the stronger Spearman correlation); see Table 1 for the definition of the abbreviations. 


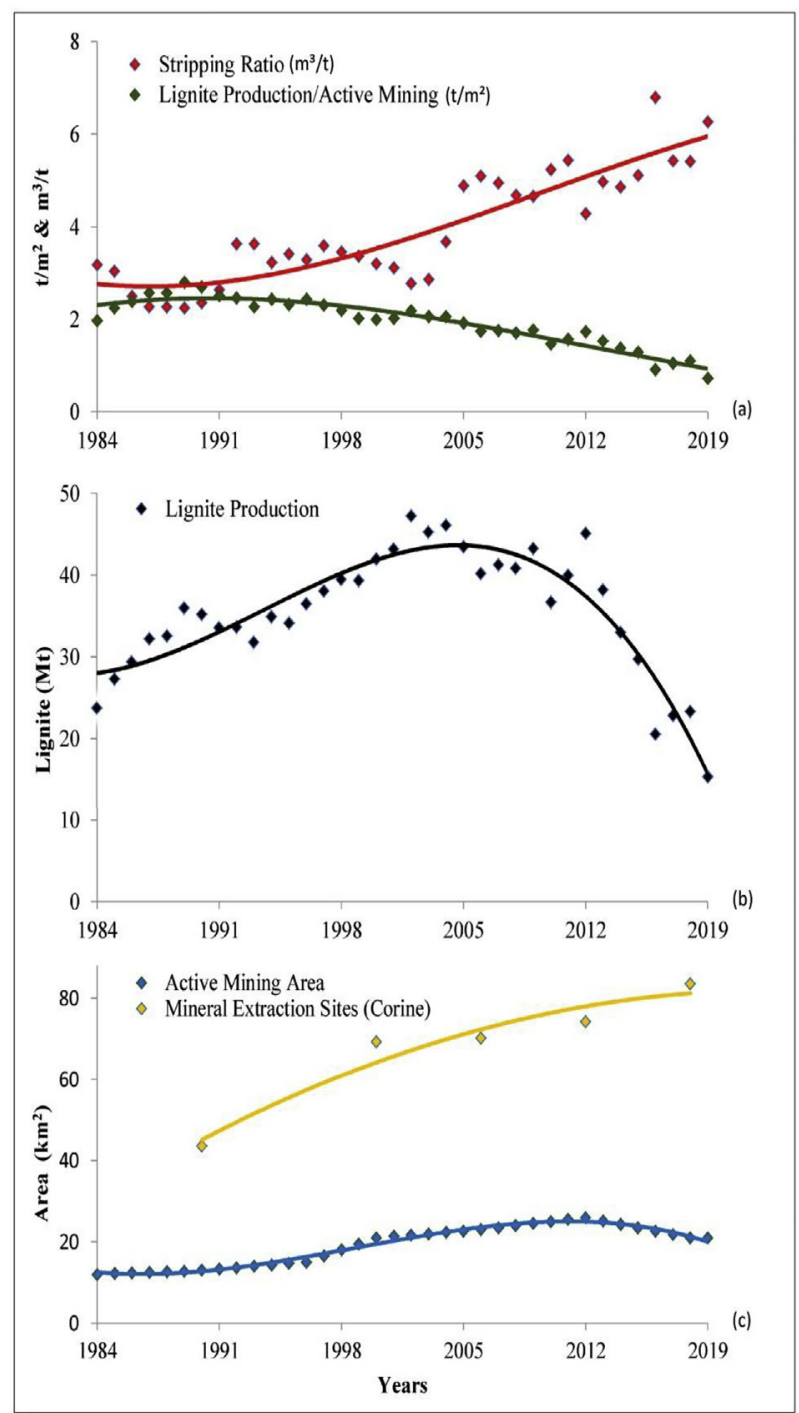

Fig. 13. Trends of mine operation parameters a) Stripping ratio is increased over time while Lignite Production to Active mining is decreased; b) Lignite production over time, c) "Mineral extraction sites" is the mineral land, according to Corine, whereas active mining area includes only the excavation areas without dumps.

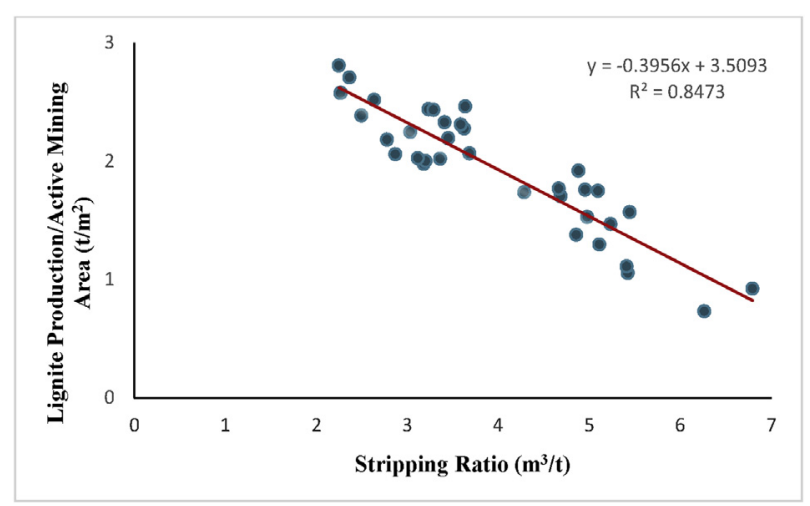

Fig. 14. Lignite production to Active mining area in linear relation with stripping ratio. the same time, the mining activities led to the creation of "green" land uses, by establishing an extensive forestation programme, fulfilling so the commitment of the mining operator for sustainable mining. It is important to point out that the percentage of $87 \%$ of forest areas in 2018 is associated with mine land reclamation works.

The study revealed that areas described as "mineral extraction sites" exhibit a strong correlation with "non-irrigated arable land" and "transitional woodland-shrubs". The former is indicative of the unavoidable impacts of mining activities on the main land uses and economic activities of the area, while the latter of the long period required for complete recovery of the ecosystem function (in the examined case, the transform of shrubs to forests of broadleaved trees).

Furthermore, the findings of this study contribute to better planning and optimal land use utilization, in the context of designing the post-mining activities. The continuous diachronically monitoring of landscape changes is considered crucial, not only in the reclaimed areas but also in the greater mining area. A combination of the study's results with geotechnical, hydrogeological, environmental, and other parameters could contribute to the landscape changes monitoring. The methods that are used in this work could also be combined with sustainable development indicators. Besides, there are pieces of evidence that the estimation of the annual changing rate of the crucial land cover/use types through the years is fundamental knowledge for the prediction of the future land cover and uses as well as the mine planning reclamation.

From the perspective of mining, accurate results regarding the linear relationship between two critical mine operation parameters have been obtained, namely the stripping ratio and the ratio of lignite production to active mining area. The reason for this linear relationship is the direct relationship between the active mining area and the area of waste rocks (overburden and interburden) excavation in combination with the definition of stripping ratio as the volume of waste material that must be excavated per tonne of lignite and the stratigraphy of the multiseam lignite deposit.

From the perspective of spatial analysis methodologies, the proposed analysis of multi-temporal land cover and use categories through enhanced transition matrix and spatial statistical tools improved the identification, quantification, and understanding of determinants of most systematic transitions. Besides, this study proved the usability of remote sensing, GIS, and Land Cover and Use processing, which can be used as efficient tools for 
mapping and monitoring the Land cover and use changes. Combining the techniques mentioned above in multi-temporal change detection analysis proved to be promising in evaluating the spatial and temporal dynamics of change compared to the conventional mapping techniques. Also, spatial information concerning the land cover locations and use changes could be a useful tool for scheduling land management plans, ensuring that activities are undertaken in appropriate locations.

In the framework of future research, interpretation and classification of satellite images for the years before 1990, would contribute to the definition and evaluation of land cover and use changes by the beginning of the mining operation. Emphasis must be given in the estimation of time that usually elapses from the expropriation of land to the completion of land reclamation works and the development of new land uses. This knowledge would be useful for planning environmental protection and land reclamation works and allocating properly the available financial sources.

\section{Conflicts of interest}

None declared.

\section{Ethical statement}

The authors state that the research was conducted according to ethical standards.

\section{Funding body}

This research received no external funding.

\section{References}

[1] Zhang B, Zhang Q, Feng C, Feng Q, Zhang S. Understanding Land Use and Land Cover Dynamics from 1976 to 2014 in Yellow River Delta. Land 2017;6:20. https://doi.org/10.3390/ land6010020.

[2] Zhang M, Wang J, Li S, Feng D, Cao E. Dynamic changes in landscape pattern in a large-scale opencast coal mine area from 1986 to 2015: A complex network approach. CATENA 2020;194:104738. https://doi.org/10.1016/j.catena.2020.104738.

[3] Hooke RLeB, Martín-Duque JF. Land transformation by humans: A review. GSA Today 2012;12:4-10. https://doi.org/ 10.1130/GSAT151A.1.

[4] Vitousek PM, Mooney HA, Lubchenco J, Melillo JM. Human Domination of Earth's Ecosystems. In: Marzluff JM, Shulenberger E, Endlicher W, Alberti M, Bradley G, Ryan C, et al., editors. Urban Ecol. Boston, MA: Springer US; 2008. p. 3-13. https://doi.org/10.1007/978-0-387-73412-5_1.

[5] Hilson G. An overview of land use conflicts in mining communities. Land Use Policy 2002;19:65-73. https:// doi.org/10.1016/S0264-8377(01)00043-6.

[6] Mertens B, Lambin EF. Land-Cover-Change Trajectories in Southern Cameroon. Ann Assoc Am Geogr 2000;90:467-94. https://doi.org/10.1111/0004-5608.00205.

[7] Pavloudakis F, Galetakis M, Roumpos Ch. A spatial decision support system for the optimal environmental reclamation of open-pit coal mines in Greece. Int J Min Reclam Environ 2009;23:291-303. https://doi.org/10.1080/17480930902731935.

[8] Turner BL, Jordan M, editors. The earth as transformed by human action: global and regional changes in the biosphere over the past 300 years; [based on papers presented at a symposium held at Clark University, Worcester, Mass. on Oct. 25 - 30, 1987]. Reprint; 1990.

[9] Kumar A, Pandey A. Evaluating Impact of Coal Mining Activity on Landuse/Landcover Using Temporal Satellite Images in South Karanpura Coalfields and Environs, Jharkhand State, India. Int J Adv Remote Sens GIS 2013;2:183-97.

[10] Latifovic R, Fytas K, Chen J, Paraszczak J. Assessing land cover change resulting from large surface mining development. Int J Appl Earth Obs Geoinformation 2005;7:29-48. https://doi.org/10.1016/j.jag.2004.11.003.

[11] Gibson PJ, Power $\mathrm{CH}$. Introductory remote sensing: digital image processing and applications. London: Routledge; 2000.

[12] Dulias R. The Impact of Mining on the Landscape: A Study of the Upper Silesian Coal Basin in Poland. Cham: Springer International Publishing; 2016. https://doi.org/10.1007/978-3319-29541-1.

[13] Upgupta S, Singh PK. Quantifying the Dynamics and Drivers of Landscape Change in an Opencast Coal Mining Area of Central India (East Bokaro, Jharkhand). Proc Natl Acad Sci India Sect Phys Sci 2020;90:565-77. https://doi.org/10.1007/ s40010-018-0589-0.

[14] Briassoulis H. Analysis of Land Use Change: Theoretical and Modeling Approaches. 2019.

[15] Khan I, Javed A. Spatio-Temporal Land Cover Dynamics in Open Cast Coal Mine Area of Singrauli, M.P., India. J Geogr Inf Syst 2012;4:521-9. https://doi.org/10.4236/jgis.2012.46057.

[16] Sonter LJ, Moran CJ, Barrett DJ, Soares-Filho BS. Processes of land use change in mining regions. J Clean Prod 2014;84: 494-501. https://doi.org/10.1016/j.jclepro.2014.03.084.

[17] Basommi PL, Guan Q, Cheng D. Exploring Land use and Land cover change in the mining areas of Wa East District, Ghana using Satellite Imagery. Open Geosci 2015;7. https:// doi.org/10.1515/geo-2015-0058.

[18] Redondo-Vega JM, Gómez-Villar A, Santos-González J, González-Gutiérrez RB, Álvarez-Martínez J. Changes in land use due to mining in the north-western mountains of Spain during the previous 50 years. CATENA 2017;149:844-56. https://doi.org/10.1016/j.catena.2016.03.017.

[19] Kiswanto, Tsuyuki S, Mardiany Sumaryono. Completing yearly land cover maps for accurately describing annual changes of tropical landscapes. Glob Ecol Conserv 2018;13: e00384. https://doi.org/10.1016/j.gecco.2018.e00384.

[20] Ahmed MA, Ahmad WA. Integration Remote Sensing and GIS Techniques to Evaluate Land Use- Land Cover of Baghdad Region and Nearby Areas. Iraqi J Sci 2014;55:9.

[21] Slonecker ET, Benger MJ. Remote sensing and mountaintop mining. Remote Sens Rev 2001;20:293-322. https://doi.org/ 10.1080/02757250109532440.

[22] Schueler V, Kuemmerle T, Schröder H. Impacts of Surface Gold Mining on Land Use Systems in Western Ghana. AMBIO 2011;40:528-39. https://doi.org/10.1007/s13280-0110141-9.

[23] Bender O, Boehmer HJ, Jens D, Schumacher KP. Analysis of land-use change in a sector of Upper Franconia (Bavaria, Germany) since 1850 using land register records. Landsc Ecol 2005;20:149-63. https://doi.org/10.1007/s10980-0031506-7.

[24] Fragou S, Kalogeropoulos K, Stathopoulos N, Louka P, Srivastava PK, Karpouzas S, et al. Quantifying Land Cover Changes in a Mediterranean Environment Using Landsat TM and Support Vector Machines. Forests 2020;11:750. https://doi.org/10.3390/f11070750.

[25] Braimoh AK. Random and systematic land-cover transitions in northern Ghana. Agric Ecosyst Environ 2006;113:254-63. https://doi.org/10.1016/j.agee.2005.10.019.

[26] Nahuelhual L, Carmona A, Aguayo M, Echeverria C. Land use change and ecosystem services provision: a case study of recreation and ecotourism opportunities in southern Chile. 
Landsc Ecol 2014;29:329-44. https://doi.org/10.1007/s10980013-9958-x.

[27] Pontius RG, Shusas E, McEachern M. Detecting important categorical land changes while accounting for persistence. Agric Ecosyst Environ 2004;101:251-68. https://doi.org/ 10.1016/j.agee.2003.09.008.

[28] Huang B, Huang J, Gilmore Pontius R, Tu Z. Comparison of Intensity Analysis and the land use dynamic degrees to measure land changes outside versus inside the coastal zone of Longhai, China. Ecol Indic 2018;89:336-47. https://doi.org/ 10.1016/j.ecolind.2017.12.057.

[29] Zhou P, Huang J, Pontius R, Hong H. Land Classification and Change Intensity Analysis in a Coastal Watershed of Southeast China. Sensors 2014;14:11640-58. https://doi.org/ 10.3390/s140711640.

[30] Fan Q, Ding S. Landscape pattern changes at a county scale: A case study in Fengqiu, Henan Province, China from 1990 to 2013. CATENA 2016;137:152-60. https://doi.org/10.1016/ j.catena.2015.09.012.

[31] Fang S, Zhao Y, Han L, Ma C. Analysis of Landscape Patterns of Arid Valleys in China, Based on Grain Size Effect. Sustainability 2017;9:2263. https://doi.org/10.3390/su9122263.

[32] Fagiewicz K, Łowicki D. The dynamics of landscape pattern changes in mining areas: The case study of the AdamówKoźmin Lignite Basin. Quaest Geogr 2019;38:151-62. https:// doi.org/10.2478/quageo-2019-0046.

[33] Liang J, Liu Y, Ying L, Li P, Xu Y, Shen Z. Road impacts on spatial patterns of land use and landscape fragmentation in three parallel rivers region, Yunnan Province, China. Chin Geogr Sci 2014;24:15-27. https://doi.org/10.1007/s11769-0140652-y.

[34] Törmä M, Markkanen T, Hatunen S, Härmä P, Mattila O-P, Arslan A. Assessment of land-cover data for land-surface modelling in regional climate studies. Boreal Environ Res 2015:243-60.

[35] European Environment Agency. CLC2006 technical guidelines. Luxembourg: Publications Office; 2007.

[36] Efthimiou N, Psomiadis E. The Significance of Land Cover Delineation on Soil Erosion Assessment. Environ Manage 2018;62:383-402. https://doi.org/10.1007/s00267-018-1044-3.

[37] Matejicek L, Kopackova V. Changes in Croplands as a Result of Large Scale Mining and the Associated Impact on Food Security Studied Using Time-Series Landsat Images. Remote Sens 2010;2:1463-80. https://doi.org/10.3390/rs2061463.

[38] Landsat Satellite Imagery n.d.. https://coast.noaa.gov/ digitalcoast/data/landsat.html. [Accessed 15 November 2020].

[39] Tewkesbury AP, Comber AJ, Tate NJ, Lamb A, Fisher PF. A critical synthesis of remotely sensed optical image change detection techniques. Remote Sens Environ 2015;160:1-14. https://doi.org/10.1016/j.rse.2015.01.006.

[40] Zhu Z. Change detection using landsat time series: A review of frequencies, preprocessing, algorithms, and applications.
ISPRS J Photogramm Remote Sens 2017;130:370-84. https:// doi.org/10.1016/j.isprsiprs.2017.06.013.

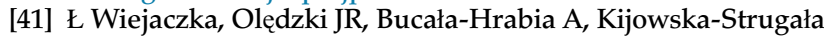
M. A Spatial and Temporal Analysis of Land Use Changes in Two Mountain Valleys: with and without Dam Reservoir (Polish Carpathians). Quaest Geogr 2017;36:129-37. https:// doi.org/10.1515/quageo-2017-0010.

[42] Costa H, Benevides P, Marcelino F, Caetano M. Introducing automatic satellite image processing into land cover mapping by photo-interpretation of airborne data ISPRS -. Int Arch Photogramm Remote Sens Spat Inf Sci 2020:29-34 https://doi.org/10.5194/isprs-archives-XLII-3-W11-29-2020. XLII-3/W11.

[43] Naranjo Gómez JM, Lousada S, Garrido Velarde JG, Castanho RA, Loures L. Land-Use Changes in the Canary Archipelago Using the CORINE Data: A Retrospective Analysis. Land 2020;9:232. https://doi.org/10.3390/ land9070232.

[44] Munsi M, Malaviya S, Oinam G, Joshi PK. A landscape approach for quantifying land-use and land-cover change (1976-2006) in middle Himalaya. Reg Environ Change 2010; 10:145-55. https://doi.org/10.1007/s10113-009-0101-0.

[45] Singh A. Review Article Digital change detection techniques using remotely-sensed data. Int J Remote Sens 1989;10: 989-1003. https://doi.org/10.1080/01431168908903939.

[46] Munthali MG, Davis N, Adeola AM, JO Botai, Kamwi JM, Chisale HLW, et al. Local Perception of Drivers of Land-Use and Land-Cover Change Dynamics across Dedza District, Central Malawi Region. Sustainability 2019;11:832. https:// doi.org/10.3390/su11030832.

[47] Peiman R. Pre-classification and post-classification changedetection techniques to monitor land-cover and land-use change using multi-temporal Landsat imagery: a case study on Pisa Province in Italy. Int J Remote Sens 2011;32:4365-81. https://doi.org/10.1080/01431161.2010.486806.

[48] Jensen JR, Lulla K. Introductory digital image processing: A remote sensing perspective. Geocarto Int 1987;2:65. https:// doi.org/10.1080/10106048709354084.

[49] Ahlqvist O. Extending post-classification change detection using semantic similarity metrics to overcome class heterogeneity: A study of 1992 and 2001 U.S. National Land Cover Database changes. Remote Sens Environ 2008;112:1226-41. https://doi.org/10.1016/j.rse.2007.08.012.

[50] Teferi E, Bewket W, Uhlenbrook S, Wenninger J. Understanding recent land use and land cover dynamics in the source region of the Upper Blue Nile, Ethiopia: Spatially explicit statistical modeling of systematic transitions. Agric Ecosyst Environ 2013;165:98-117. https://doi.org/10.1016/ j.agee.2012.11.007.

[51] Pavloudakis F, Roumpos Ch, Galetakis M. Public acceptance of surface mining projects and the determination of the marginal environmental cost. Int J Min Reclam Environ 2012; 26:292-308. https://doi.org/10.1080/17480930.2011.613568. 